\title{
The impacts of firework burning at the Chinese Spring Festival on air quality: insights of tracers, source evolution and aging processes
}

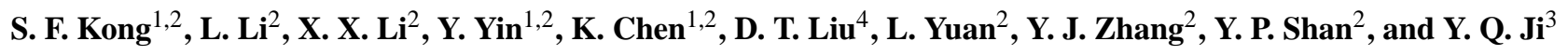 \\ ${ }^{1}$ Collaborative Innovation Center on Forecast and Evaluation of Meteorological \\ Disasters, Nanjing University of Information Science and Technology, Nanjing, 210044, China \\ ${ }^{2}$ Key Laboratory for Aerosol-Cloud-Precipitation of China Meteorological Administration, School of \\ Atmospheric Physics, Nanjing University of Information Science \& Technology, Nanjing 210044, China \\ ${ }^{3}$ College of Environmental Science and Engineering, Nankai University, Tianjin, 100086, China \\ ${ }^{4}$ School of Earth, Atmospheric and Environmental Science, University of Manchester, Manchester, UK \\ Correspondence to: Y. Yin (yinyan@ nuist.edu.cn); Y. Q. Ji (jiyaqin@nankai.edu.cn) and S. F. Kong (kongshaofei@ 126.com)
}

Received: 1 October 2014 - Published in Atmos. Chem. Phys. Discuss.: 19 November 2014

Revised: 28 January 2015 - Accepted: 2 February 2015 - Published: 27 February 2015

\begin{abstract}
To understand the impact of firework-burning (FW) particles on air quality and human health during the winter haze period, 39 elements, 10 water-soluble ions and 8 fractions of carbonaceous species in atmospheric $\mathrm{PM}_{2.5}$ in Nanjing were investigated during the 2014 Chinese Spring Festival (SF). Serious regional haze pollution persisted throughout the entire sampling period, with $\mathrm{PM}_{2.5}$ averaging at $113 \pm 69 \mu \mathrm{g} \mathrm{m}^{-3}$ and visibility at $4.8 \pm 3.2 \mathrm{~km}$. The holiday effect led to almost all the chemical species decreasing during the SF, except for $\mathrm{Al}, \mathrm{K}, \mathrm{Ba}$ and $\mathrm{Sr}$ which were related to FW. The source contributions of coal combustion, vehicle emission and road dust decreased dramatically, whereas FW contributed to about half of the $\mathrm{PM}_{2.5}$ during the SF period. The intensive emission of FW particles on New Year's Eve accounted for $60.1 \%$ of the $\mathrm{PM}_{2.5}$. Fireworks also obviously modified the chemical compositions of $\mathrm{PM}_{2.5}$, with $39.3 \%$ contributed by increased organic matter, followed by steadily increased loadings of secondary inorganic ions. The aging processes of the FW particles lasted for about 4 days reflected by the variations of $\mathrm{Ba}, \mathrm{Sr}, \mathrm{NH}_{4}^{+}$, $\mathrm{NO}_{3}^{-}, \mathrm{SO}_{4}^{2-}$ and $\mathrm{K}^{+}$, characterized by heterogeneous reactions of $\mathrm{SO}_{2}$ and $\mathrm{NO}_{\mathrm{x}}$ on crustal materials directly from $\mathrm{FW}$, the replacement of $\mathrm{Cl}^{-}$by $\mathrm{NO}_{3}^{-}$and $\mathrm{SO}_{4}^{2-}$, coating of $\mathrm{NO}_{3}^{-}$and $\mathrm{SO}_{4}^{2-}$ on soot, formation of secondary organic aerosols and metal-catalyzed formation of $\mathrm{NO}_{3}^{-}$and $\mathrm{SO}_{4}^{2-}$ at higher relative humidity. During aging, the main contributors to the extinction coefficient shifted from elemental carbon and organic matter to ammonium sulfate. The particles
\end{abstract}

raised higher cancer risk of $1.62 \times 10^{-6}$ by heavy metals (especially for $\mathrm{Cd}$ and As). This study provided detailed composition data and first comprehensive analysis of the aging processes of FW particles during the serious haze pollution period and their potential impact on human health.

\section{Introduction}

Atmospheric pollutants emitted from firework burning (FW) at festivals or special celebration events around the world have recently received wide attention, such as Guy Fawkes night in the UK (Allan et al., 2010; Godri et al., 2010), Pyronale $^{\circledR} 2009$ and Pyromusikale ${ }^{\circledR}$ (Dutschke et al., 2011), Montréal international fireworks competition (Joly et al., 2010), New Year's celebrations (Williams et al., 2005; Drewnick et al., 2006; Zhang et al., 2010; Do et al., 2012; Feng et al., 2012; Jiang et al., 2014; Jing et al., 2014; Tian et al., 2014; Ye et al., 2014), Diwali (Godri et al., 2010), Las Fallas in Valencia (Moreno et al., 2007), the new Millennium celebration in Germany (Wehner et al., 2000), 2006 FIFA World Cup (Vecchi et al., 2008) and Lantern Festival (Do et al., 2012; Tsai et al., 2012). Besides the direct possible dangers like exposure to sound pressure (Dutschke et al., 2011) or firework-related injuries (Do et al., 2012), their burning results in massive quantities of pollutants, leading to degradation of air quality (Wang et al., 2007; Sarkar et al., 2010; Dutschke et al., 2011; Do et al., 2012; Feng et al., 
2012; Tsai et al., 2012; Jiang et al., 2014; Jing et al., 2014; Tian et al., 2014; Yang et al., 2014) and raising serious human health concerns (Godri et al., 2010; Do et al., 2012). Evidence suggests that inhalation of fumes containing high levels of specific elements such as chlorine can cause mucosal irritation and acute respiratory distress syndrome (Joly et al., 2010). A toxicity study reported that the samples collected in the post-FW period were more toxic than those in the pre-FW period according to the viabilities of BEAS-2B cells after $24 \mathrm{~h}$ incubation with the particle extracts (Do et al., 2012). A positive significant relationship was also found between particulate matter oxidative burden and individual trace metals associated with FW (Godri et al., 2010).

China is the largest firework producing country in the world (Tian et al., 2014). For the Chinese New Year day (CNY, in the Spring Festival (SF) on January or February of lunar Chinese calendar, high-profile FW events occurred at midnight of the CNY's Eve in national scale, from small villages to megacities. It should be noted that FW events always occurred in an already highly polluted urban air in China (Supplement Fig. S1). In winter, increased coal consumption for heating (Li and Zhang, 2014) and stable atmospheric conditions always raise serious haze pollution in central and eastern China. On January 2013, all of central and eastern China was shrouded in a long-lasting severe haze episode (Wang et al., 2014). According to the Chinese Ministry of Environmental Protection, on 31 January 2014, about $80 \%$ of 161 cities held average $\mathrm{PM}_{2.5}$ concentrations higher than $150 \mu \mathrm{g} \mathrm{m}^{-3}$ (Ye et al., 2014). The addition of pollutants from FW deteriorates ambient air quality during the SF and its impact can vary significantly with FW duration and meteorological conditions (Vecchi et al., 2008; Yu et al., 2013).

Previous studies have extensively characterized the physicochemical signatures of FW emissions, such as gaseous pollutants (Wehner et al., 2000; Attri et al., 2001; Williams et al., 2005; Drewnick et al., 2006; Wang et al., 2007; Vecchi et al., 2008; Tan et al., 2009; Godri et al., 2010), particle size distribution and number concentration (Wehner et al., 2000; Drewnick et al., 2006; Vecchi et al., 2008; Zhang et al., 2010; Dutschke et al., 2011; Yang et al., 2014), chemical components including trace elements (Wang et al., 2007; Moreno et al., 2007; Vecchi et al., 2008; Estrellan and Iino, 2010; Godri et al., 2010; Joly et al., 2010; Do et al., 2012; Tsai et al., 2012; Tian et al., 2014; Yang et al., 2014), organic carbon (OC) and elemental carbon (EC) (Estrellan and Iino, 2010; Feng et al., 2012; Tsai et al., 2012; Tian et al., 2014; Yang et al., 2014) and water-soluble ions (Wang et al., 2007; Vecchi et al., 2008; Shen et al., 2009; Estrellan and Iino, 2010; Tsai et al., 2012; Wang et al., 2013; Jiang et al., 2014; Tian et al., 2014; Yang et al., 2014). Recently, single particle's chemical compositions (Drewnick et al., 2006; Allan et al., 2010; Jiang et al., 2014), morphology and mixing properties (Li et al., 2013) and optical properties (Yu et al., 2013) of FW particles had been reported. However, there are now still two issues needed to be explicitly addressed.
Firstly, no studies reported the chemical compositions (crustal elements, trace elements, water-soluble ions, OC and EC) of FW particles completely, considering the complex manufacture materials of FW (Supplement Fig. S2). Although Estrellan and Iino (2010), Feng et al. (2012), Yang et al. (2014) and Tian et al. (2014) reported the ions, elements and carbonaceous species synchronously, some important species were missed, such as $\mathrm{Na}, \mathrm{Mg}, \mathrm{K}, \mathrm{Ti}, \mathrm{NH}_{4}^{+}$and $\mathrm{Cl}^{-}$in Tian et al. (2014), OC in Estrellan and lino (2010), Si and some heavy elements in Feng et al. (2012) and crustal elements in Yang et al. (2014). These species are all highly elevated during FW events. Crustal elements including $\mathrm{Na}, \mathrm{Mg}$, $\mathrm{Al}, \mathrm{Si}, \mathrm{K}, \mathrm{Ca}, \mathrm{Ti}, \mathrm{Fe}$ and $\mathrm{Mn}$ were always missing or not sufficiently studied in FW particles. However, except for inorganic and organic chemicals such as charcoal, potassium nitrate, potassium chlorate, potassium perchlorate, sulfur, manganese, sodium oxalate, aluminum, iron powder, strontium nitrate, and barium nitrate (Shen et al., 2009; Jing et al., 2014), clay is also used to seal the top and bottom of fireworks as shown in the Supplement Fig. S3. $90 \%$ of the total mineral aerosol was from the emission of $\mathrm{FW}$ on the lantern night in Beijing (Wang et al., 2007). The incomplete compositions of FW particles may bias the identification of particle sources during the FW period and limit our understanding of its aging processes. For example, crustal elements-Al, $\mathrm{Si}$ and $\mathrm{Ca}$ were thought to result from the resuspension of materials already deposited on the ground (caused by pyrotechnic device explosions) and hereby the resuspended dust was regarded as a contributor to atmospheric particles during SF (Tian et al., 2014). Without detecting the crustal and trace elements, secondary particulate matter accounted for $63-82 \%$ of $\mathrm{PM}_{1.0}$ during FW periods in Beijing (Jiang et al., 2014).

Secondly, all the former studies unanimously agreed that FW contributed to elevated concentrations of particles and associated chemical species, but no studies concerned the aging processes of particles after being emitted from intensive FW. The cocktail of primary pollutants released may exhibit varied interactions among themselves, and if aided by favorable atmospheric conditions, may lead to the formation of secondary pollutants (Sarkar et al., 2010). Do et al. (2012) pointed that the sub-micron aerosol or accumulation-mode particles from FW can suspend in the air for very long periods, from days to weeks, potentially causing pollution to large areas. Data in literature verified the existence of aging processes of FW particles, though it has not been discussed. For example, Li et al. (2013) indicated that emissions from $\mathrm{FW}$ changed the transformation pathway from $\mathrm{SO}_{2}$ to $\mathrm{SO}_{4}^{2-}$ and the FW particles can influence the air at the downwind site (50 km far away). And after about 2 days, the elevated $\mathrm{PM}_{2.5}$ mass concentrations on CNY's Eve decreased to the level of the day before CNY (pre-CNY). In Beijng, $\mathrm{PM}_{2.5}$ mass concentrations on CNY's Eve decreased to the level of pre-CNY in one day, while secondary ions $\left(\mathrm{SO}_{4}^{2-}, \mathrm{NH}_{4}^{+}\right.$and $\mathrm{NO}_{3}^{-}$) and organic matter $(\mathrm{OM})$ increased first and then de- 
creased to the level of pre-CNY after 3 days (Wang et al., 2007). In Jinan, a "tailing" phenomena was found, indicating that $\mathrm{NH}_{4}^{+}$and $\mathrm{NO}_{3}^{-}$did not increase (peaking at 08:00 and 12:00, respectively) immediately with the concentrations of particles (peaking at 00:00) after emitted on CNY's Eve (Yang et al., 2014). In Shanghai, $\mathrm{NH}_{4}^{+}$and $\mathrm{NO}_{3}^{-}$also increased in the first day after emitted on CNY's Eve and then decreased to the level of pre-CNY in the third day, and the decreasing rate of $\mathrm{PM}_{2.5}$ was faster than that for OC (Feng et al., 2012). Therefore, we still need to answer the following questions. (1) Are the decreasing trends of particles and associated chemical components the same? (2) How long and how far can FW influence the air quality at certain meteorological conditions? (3) During aging and transport, which type of chemical reactions will the FW particles undergo and how will specific chemical ratios vary?

Due to rapid economic expansion and urbanization, the occurrence frequency of haze has increased rapidly in recent 30 years in the Yangtze River Delta region (Wang et al., 2014). As one of the central megacities of this region, Nanjing is suffering from serious air pollution and the occurrence of hazy days increased from 1961 to 2005 (Kang et al., 2013). Thus, it provides a unique site and opportunity to study the chemical composition evolution and source variation during haze-clear days with the injection of intensive FW during the SF. The main purposes of this study are to (1) characterize in detail the chemical compositions of atmospheric $\mathrm{PM}_{2.5}$ before, during and after intensive FW events; (2) identify how long and how much can the FW particles influence $\mathrm{PM}_{2.5}$ by tracer analysis and receptor models; (3) emphasize how can the FW particles affect visibility and human cancer and noncancer risks; (4) analyze the FW particle aging processes by specific species and ratios. The data and analysis will improve the knowledge of chemical compositions of FW particles, their evolution during serious haze pollution periods and their influence on visibility and human health.

\section{Methodology}

\section{1 $\mathbf{P M}_{2.5}$ collection}

From 24 January to 21 February 2014, a sampling campaign of $\mathrm{PM}_{2.5}$ was conducted on the rooftop ( $40 \mathrm{~m}$ high) of a building in Nanjing University of Information Science \& Technology (NUIST) (Kang et al., 2013; Wang et al., 2014). It is a suburban site, surrounded by residential communities at the west, south, north and southeast directions. There is a steel factory $2 \mathrm{~km}$ to the east of the campus and a chemical industry park about $10 \mathrm{~km}$ to the northeast. It faces one road with heavy traffic, about $200 \mathrm{~m}$ in the east. Location of the sampling site was shown in Fig. 1 and Supplement Fig. S4. During the sampling period, CNY on 30 January and Lantern Festival (LF) on 14 February were included. On CNY's and LF's Eve, numerous fireworks were consumed. The SF hol-

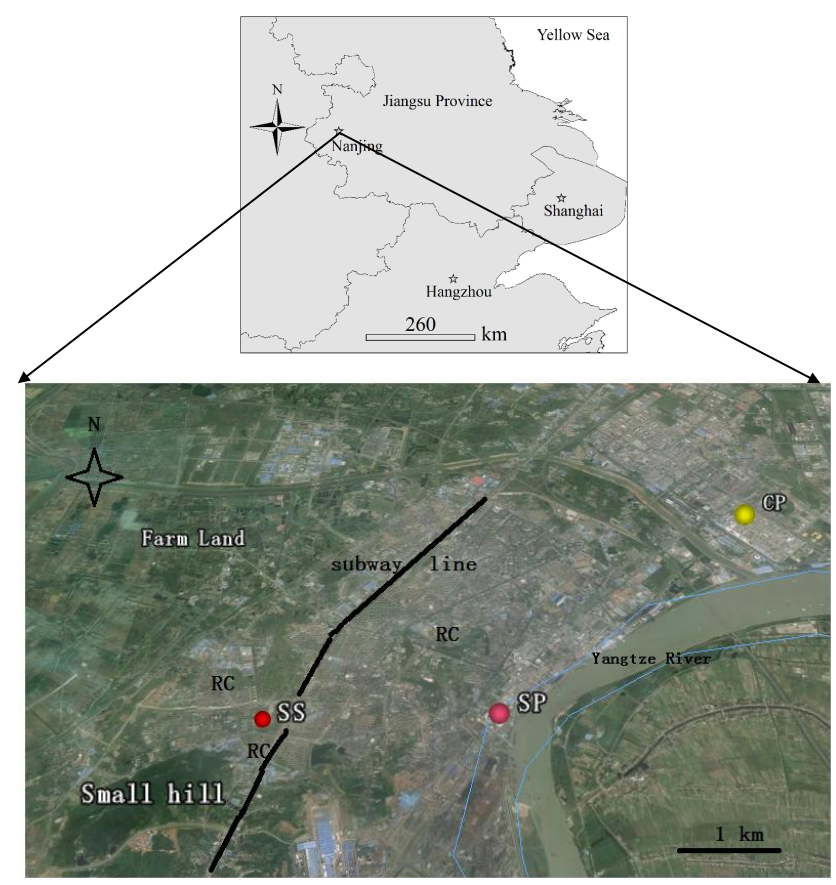

Figure 1. Location of the sampling site (the red dot, SS). SP: iron smelt plant; CP: chemical industrial park; RC: residential community. The black line indicates the subway line near SS.

iday was from 30 January to 7 February. Each day, $\mathrm{PM}_{2.5}$ samples were collected at about 08:00 am for $24 \mathrm{~h}$ using two medium-volume air samplers (TH-150C, Wuhan Tianhong Ltd., China) on quartz fiber filters (baked at $800^{\circ} \mathrm{C}$ for $2 \mathrm{~h}$ ) and polypropylene fiber filters (baked at $80^{\circ} \mathrm{C}$ for $0.5 \mathrm{~h}$ ) at a flow rate of $100 \mathrm{~L} \mathrm{~min}^{-1}$. The hourly online $\mathrm{PM}_{2.5}$ mass concentrations for the nine monitoring sites set by Jiangsu Environmental Monitoring Center were collected from the pubic platform (http://218.94.78.75/jsair/) (their locations can be found in Supplement Fig. S4). A total of 24 pairs of filter samples were obtained (Supplement Fig. S5). By using a microbalance (Ohaus Discovery DV214CD) with balance sensitivity as $\pm 0.010 \mathrm{mg}$, filters were weighed before and after sampling under controlled environment with temperature and relative humidity (RH) of $22^{\circ} \mathrm{C}$ and $35 \%$. Then they were stored at $-20^{\circ} \mathrm{C}$ until chemical analysis. The quartz fiber filters were for analyzing water-soluble inorganic ions, OC and EC. Polypropylene fiber filters were for elemental analysis.

\subsubsection{Chemical analysis}

Inductively coupled plasma-mass spectroscopy (ICP-MS) (Agilent 7500a, Agilent Co. USA) was used for analyzing $\mathrm{Li}, \mathrm{Be}, \mathrm{Na}, \mathrm{Mg}, \mathrm{Al}, \mathrm{P}, \mathrm{K}, \mathrm{Ca}, \mathrm{Sb}, \mathrm{Sc}, \mathrm{Ti}, \mathrm{V}, \mathrm{Cr}, \mathrm{Mn}, \mathrm{Co}$, $\mathrm{Ni}, \mathrm{Cu}, \mathrm{Zn}, \mathrm{As}, \mathrm{Rb}, \mathrm{Y}, \mathrm{Mo}, \mathrm{Cd}, \mathrm{Sn}, \mathrm{Cs}, \mathrm{La}, \mathrm{Ce}, \mathrm{Sm}, \mathrm{W}$, $\mathrm{Tl}, \mathrm{Pb}, \mathrm{Bi}$, Th and $\mathrm{U}$. Nine elements including $\mathrm{Si}, \mathrm{Al}, \mathrm{Ca}$, $\mathrm{Mg}, \mathrm{Fe}, \mathrm{Ti}, \mathrm{Ba}, \mathrm{Sr}$ and $\mathrm{Zr}$ were analyzed by inductively cou- 
pled plasma-optical emission spectrometer (ICP-OES). Al, $\mathrm{Ca}, \mathrm{Mg}$ and Ti were analyzed by both ICP-MS and ICP-OES, and results from the latter were used as the analysis accuracy for the four elements by ICP-OES was better than that by ICP-MS (Kong et al., 2014a). A total of 10 ions including $\mathrm{NH}_{4}^{+}, \mathrm{Na}^{+}, \mathrm{Mg}^{2+}, \mathrm{K}^{+}, \mathrm{Ca}^{2+}, \mathrm{F}^{-}, \mathrm{Cl}^{-}, \mathrm{NO}_{2}^{-}, \mathrm{NO}_{3}^{-}$and $\mathrm{SO}_{4}^{2-}$ were analyzed by a professional ion chromatograph (Wan Tong 850, Switzerland). The DRI (Desert Research Institute) Model 2001 (thermal/optical carbon analyzer) with the IMPROVE thermal/optical reflectance protocol was used for OC and EC analysis (Han et al., 2008; Han et al., 2010; Huang et al., 2012; Li et al., 2012; Wang et al., 2013; Kong et al., 2014a). A $0.188 \mathrm{~cm}^{2}$ punch area from the quartz filter was heated to produce four OC fractions: $\mathrm{OC} 1, \mathrm{OC} 2, \mathrm{OC} 3$ and $\mathrm{OC} 4$ at temperatures of $120,250,450$ and $550{ }^{\circ} \mathrm{C}$ in a non-oxidizing $\mathrm{He}$ atmosphere, three EC fractions: EC1, EC2 and $\mathrm{EC} 3$ at 550,700 and $800^{\circ} \mathrm{C}$ in an oxidizing atmosphere of $2 \% \mathrm{O}_{2} / 98 \% \mathrm{He}$ and optically detected pyrolyzed carbon (OPC). OC is defined as $\mathrm{OC} 1+\mathrm{OC} 2+\mathrm{OC} 3+\mathrm{OC} 4+\mathrm{OPC}$ and $\mathrm{EC}$ is calculated by $\mathrm{EC} 1+\mathrm{EC} 2+\mathrm{EC} 3-\mathrm{OPC}$. Char-EC is defined as EC1 minus OPC, and soot-EC is the sum of EC2 and EC3 (Han et al., 2008, 2010). The pre-treatment and chemical analysis procedures and quality assurance and control are described in detail in our previous works ( $\mathrm{Li}$ et al., 2012, 2014; Kong et al., 2014a, b).

\subsection{Meteorological parameters}

The meteorological parameters including relative humidity (RH), visibility, wind speed, wind direction and temperature were recorded by the meteorological observatory of our university (http://qxt.nuist.edu.cn/). The rainfall information was obtained from http://www.wunderground.com/. According to China Meteorological Administration, fog is defined as visibility $<10 \mathrm{~km}$ and $\mathrm{RH}>90 \%$ and haze is defined as visibility $<10 \mathrm{~km}$ and $\mathrm{RH}<80 \%$. For visibility $<10 \mathrm{~km}$ and $80 \%<\mathrm{RH}<90 \%$, is a fog-haze mixing day. Fig. 2 shows that the visibilities are generally below $10 \mathrm{~km}$ (averaged as $4.8 \pm 3.2 \mathrm{~km}$ ), indicating fog, haze or fog-haze mixing events frequently occurred. On 4 February, a strong cold front passed through, leading to high visibility $(14.7 \mathrm{~km})$, low temperature $\left(2.4^{\circ} \mathrm{C}\right)$ and high wind speed $\left(3.5 \mathrm{~m} \mathrm{~s}^{-1}\right)$. The wind speed remained mostly below $3 \mathrm{~m} \mathrm{~s}^{-1}$ (averaged as $2.2 \pm 0.7 \mathrm{~m} \mathrm{~s}^{-1}$ ), suggesting stagnant weather conditions.

\subsection{Data processing}

\subsubsection{Back trajectory calculation}

Three-day air mass back trajectories are calculated using NOAA Air Resource Lab HYSPLIT 4.8 model, driven by the GDAS meteorological data set $\left(1^{\circ} \times 1^{\circ}\right)$ (Kong et al., 2014b). A $72 \mathrm{~h}$ back trajectory is adopted with the starting height of $500 \mathrm{~m}$ above ground level (Huang et al., 2012). Cluster analysis is adopted, which results in subsets of trajec-
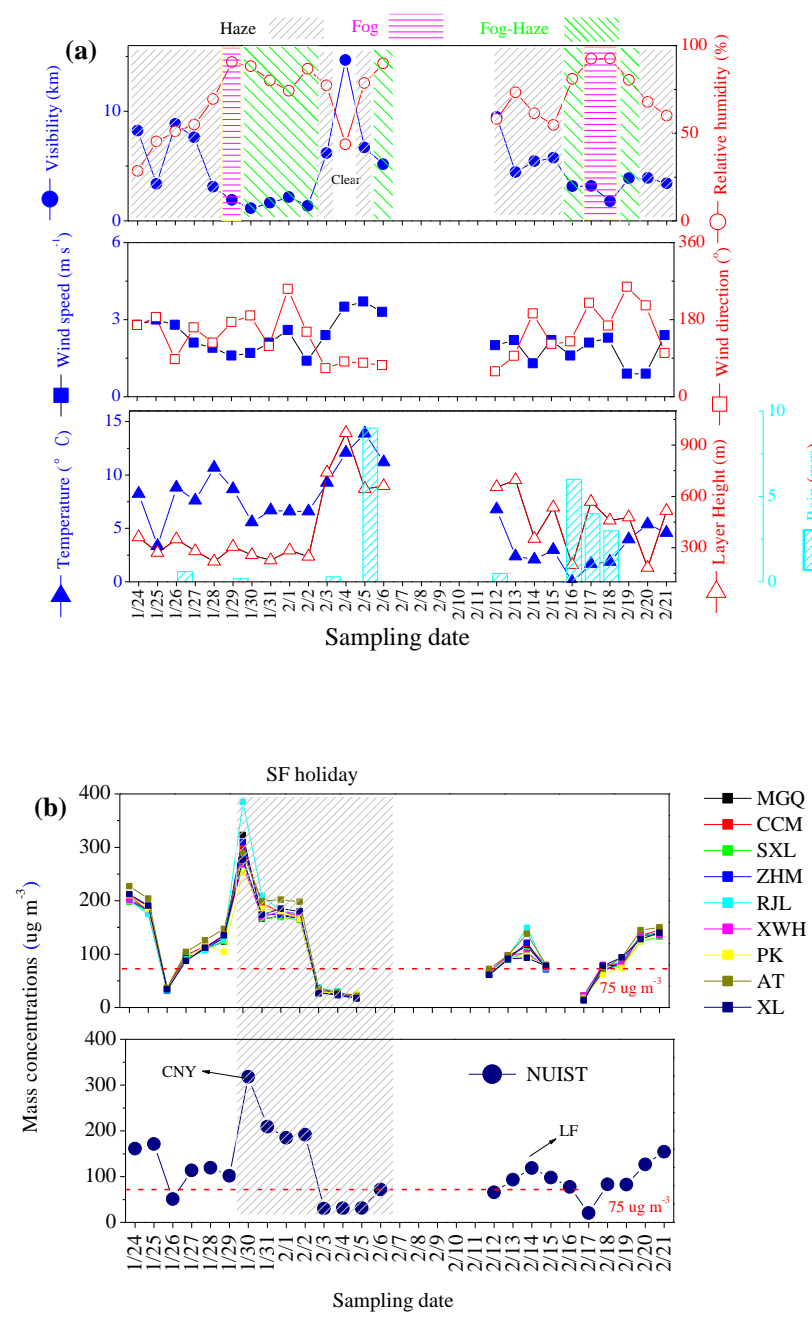

Figure 2. Daily variation of meteorological factors (a) and mass concentrations of $\mathrm{PM}_{2.5}$ (b) during sampling periods. MGQ, CCM, SXL, ZHM, RJL, XWH, PK, AT and XL indicate the nine urban air quality monitoring sites set by Jiangsu Environmental Monitoring Center as Supplement Fig. S4 shown. NUIST indicates the sampling site of this study at Nanjing University of Information Science and Technology. SF means Spring Festival (between 30 January7 February); CNY means Chinese New Year day (30 January); LF means Lantern Festival day (14 February). $75 \mu \mathrm{g} \mathrm{m}^{-3}$ is the $24 \mathrm{~h}$ averaged secondary standard value for $\mathrm{PM}_{2.5}$ of China National Ambient Air Quality Standards.

tories with backward trajectories computed every $6 \mathrm{~h}(00: 00$, 06:00, 12:00 and 18:00) each day. The clustering process is described in detail in Hysplit User's Guide-Version 4. The mixing layer height is calculated every $3 \mathrm{~h}$ each day by the NOAA's READY Archived Meteorology online calculating program (http://ready.arl.noaa.gov/READYamet.php). This program produces a time series of calculated boundary layer depth using the chosen meteorological data. As shown in Fig. 3, 43\% (cluster 3, 4 and 5) of the air masses that originated from Mongolia and crossed Chinese coastal seas; 


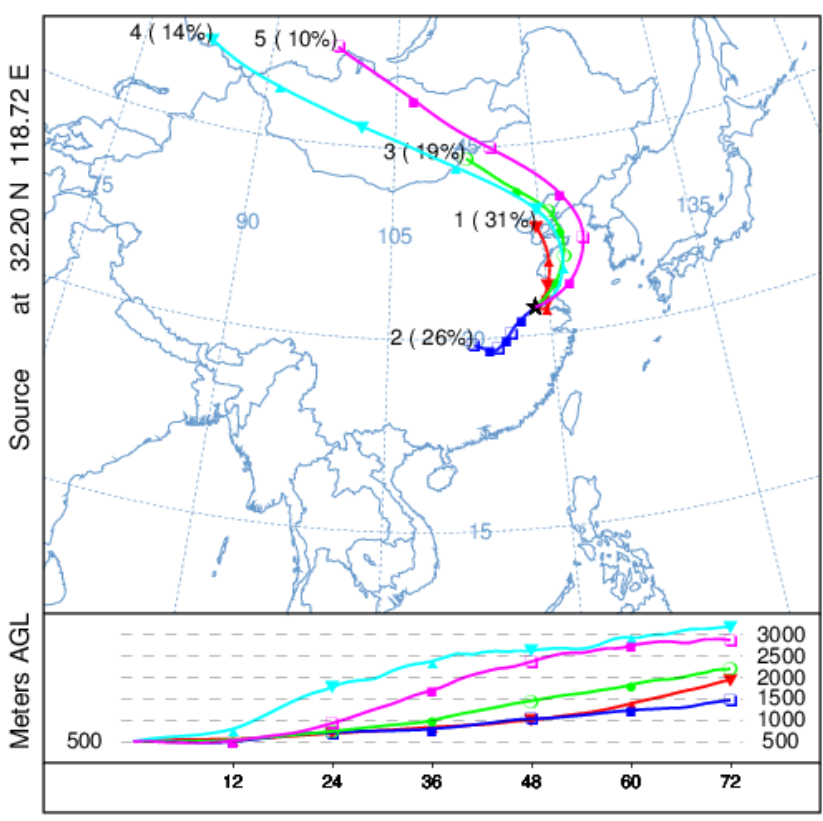

Figure 3. Cluster analysis for backward trajectories of air masses during the whole sampling periods. The different colors indicated different clusters of the backward trajectories.

$31 \%$ (cluster 1) was from the north China and transported across Shandong Peninsula; $26 \%$ (cluster 2) was from central China. Cluster 1 and cluster 2 transported for short distances, which may easily raise regional air pollution, as the Shandong Peninsula and central and eastern China hold intensive anthropologic sources for air pollutants.

\subsubsection{Principal component analysis}

Principal component analysis (PCA) is used to identify the sources for particles at periods before (24-29 January), during (30 January-6 February), after SF holiday (12-21 February) and the whole period. It can analyze multivariate data-set structure and identify a smaller number of independent factors to explain the data variance. Factor loadings are related to the source emission compositions. A varimax normalized rotation is adopted by SPSS 13.0 software in this study (Kong et al., 2010).

\subsubsection{Health risk assessment of heavy metals}

After emitted, the heavy metals in FW particles can raise risks to human health. To raise the public's attention to the health threat of FW particles, the average amount of heavy metal exposure by inhalation ( $D_{\text {inh }}$ ) per an individual's body weight over a given time span for adults and children was calculated by following equation (Kong et al., 2012; Yang et al., 2014):

$D_{\text {inh }}\left(\mathrm{mg} \mathrm{kg}^{-1}\right.$ day $\left.^{-1}\right)=\frac{C \times \mathrm{InhR} \times \mathrm{EF} \times \mathrm{ED}}{\mathrm{BW} \times \mathrm{AT}}$.
The lifetime average daily dose (LADD) of $\mathrm{Co}, \mathrm{Ni}$, As and $\mathrm{Cd}$ exposure through inhalation was used for assessing cancer risk as follows:

$\mathrm{LADD}=\frac{C \times \mathrm{EF}}{\mathrm{AT}} \times\left(\frac{\mathrm{InhR}_{\text {child }} \times \mathrm{ED}_{\text {child }}}{\mathrm{BW}_{\text {child }}}+\frac{\mathrm{InhR}_{\text {adult }} \times \mathrm{ED}_{\text {adult }}}{\mathrm{BW}_{\text {adult }}}\right)$,

where $\mathrm{C}$ is exposure-point concentration. Its upper limit of the $95 \%$ confidence interval for the mean is calculated as

$C_{95 \% \mathrm{UCL}}=\exp \left(\bar{X}+0.5 \mathrm{~s}^{2}+\frac{s \times H}{\sqrt{n-1}}\right)$,

where $\bar{X}$ is the arithmetic mean of the log-transformed data, s is the standard deviation of the log-transformed data, $H$ is the $H$-statistic and $n$ is the number of samples. InhR is inhalation rate, 7.6 and $20 \mathrm{~m}^{3} \mathrm{day}^{-1}$ for children and adults; EF is exposure frequency, 4 day year ${ }^{-1}$ in this study (according to the discussion in Section 3.4.2); ED is exposure duration, 6 and 24 years for children and adults; BW is average body weight; 15 and $70 \mathrm{~kg}$ for children and adults; AT is the averaging time, for non-carcinogens, AT (days) $=\mathrm{ED} \times 365$; for carcinogens, AT (days) $=70 \times 365=25550$.

After the $D_{\text {inh }}$ is calculated, a Hazard Quotient (HQ) for non-cancer toxic risk can be obtained by (Kong et al., 2012)

$\mathrm{HQ}=D / \mathrm{RfD}$.

Considering the sensitive group, the reference dose (RfD) $\left(\mathrm{mg} \mathrm{kg}^{-1} \mathrm{day}^{-1}\right)$ is estimated as the maximum permissible risk on human by daily exposure. The threshold values of RfD indicate whether there is adverse health effect during a life time. Then, hazard index (HI) can be obtained by summing up the individual HQ to estimate the total risks of all elements considered:

$\mathrm{HI}=\sum \mathrm{HQ}_{i}$,

where $i$ denotes different heavy metals. RfD values are $7 \times 10^{-3}, 2.86 \times 10^{-5}, 1.43 \times 10^{-5}, 4.0 \times 10^{-2}, 3.0 \times 10^{-1}$ and $3.5 \times 10^{-3}$ for the cancer risk estimation of $\mathrm{V}, \mathrm{Cr}, \mathrm{Mn}$, $\mathrm{Cu}, \mathrm{Zn}$ and $\mathrm{Pb}$. For non-cancer risk estimation of $\mathrm{Co}, \mathrm{Ni}$, As and $\mathrm{Cd}$, the RfD values are $5.71 \times 10^{-6}, 2.00 \times 10^{-2}$, $3.00 \times 10^{-4}$ and $1.00 \times 10^{-3}$, respectively (Kong et al., 2012). If $\mathrm{HI} \leq 1$, there are no adverse health effects; if $\mathrm{HI}>1$, likely adverse health effects exist. For carcinogens, the LADD is multiplied by the corresponding RfD value (they are $9.8 \times 10^{0}, 8.4 \times 10^{-1}, 1.51 \times 10^{1}$ and $6.3 \times 10^{0}$ for $\mathrm{Co}$, $\mathrm{Ni}$, As and Cd, respectively) (Kong et al., 2012). For cancer risk, the value of $10^{-6}$ is an internationally accepted precautionary or threshold value above which the risk is unacceptable (Granero and Domingo, 2002; Baptistaa and Miguel, 2005).

\subsubsection{Mass closure of $\mathbf{P M}_{2.5}$}

To better understand the chemical compositions before, during and after the SF, the chemical mass closure analysis 
was conducted. The chemical components are divided into six classes as follows: mineral matter (MIN), trace elements (TE), OM, EC, sea salt (SS), secondary inorganic aerosol (SIA) and unidentified matter (UM). MIN is the sum of the common oxides of $\mathrm{Al}, \mathrm{Mg}, \mathrm{Mn}, \mathrm{Si}, \mathrm{Na}, \mathrm{K}, \mathrm{Ca}$, Ti and $\mathrm{Fe}$ as

$$
\begin{aligned}
\mathrm{MIN} & =2.14 \times \mathrm{Si}+1.67 \times \mathrm{Ti}+1.89 \times \mathrm{Al}+1.59 \\
& \times \mathrm{Mn}+1.67 \times \mathrm{Mg}+1.95 \times \mathrm{Ca}+1.35 \times \mathrm{Na}+1.21 \\
& \times \mathrm{K}+1.43 \times \mathrm{Fe} .
\end{aligned}
$$

As the existence of $\mathrm{CaO}$ and $\mathrm{CaCO}_{3}$, a factor of 1.95 for $\mathrm{Ca}$ is used (Terzi et al., 2010). Except for the above elements in MIN, all other elements are summed up to act as TE. OM is calculated by multiplying OC of a conversion factor, in accordance with the organic molecular carbon weight per carbon weight. The factor 2.0 is applied here, which is also used for the spring festival period in Shanghai, another megacity in the Yangtze River Delta region (Huang et al., 2012). In Allan et al. (2010), during bonfires and the firework-burning period on Guy Fawkes night, the OM/OC ratio ranged around 2.0 or higher than 2.0. The marine contribution is calculated based on a standard sea water composition, assuming that soluble $\mathrm{Na}^{+}$in aerosols only come from sea salt. Then,

$$
\begin{aligned}
& \text { sea salt }=\left[\mathrm{Na}^{+}\right]+\left[\mathrm{ss}^{-} \mathrm{Cl}^{-}\right]+\left[\mathrm{ss}-\mathrm{Mg}^{2+}\right]+\left[\mathrm{ss}-\mathrm{K}^{+}\right] \\
& +\left[\mathrm{ss}^{-\mathrm{Ca}^{2+}}\right]+\left[\mathrm{ss}^{2}-\mathrm{SO}_{4}^{2-}\right],
\end{aligned}
$$

where $\quad \mathrm{ss}^{-\mathrm{Cl}^{-}}=1.8 \times\left[\mathrm{Na}^{+}\right], \quad \mathrm{ss}-\mathrm{Mg}^{2+}=0.12 \times\left[\mathrm{Na}^{+}\right]$, ss- $\mathrm{K}^{+}=0.036 \times\left[\mathrm{Na}^{+}\right], \quad$ ss-Ca ${ }^{2+}=0.038 \times\left[\mathrm{Na}^{+}\right], \quad$ and ss- $\mathrm{SO}_{4}^{2-}=0.252 \times\left[\mathrm{Na}^{+}\right]$(Terzi et al., 2010). SIA is the sum of nss- $\mathrm{SO}_{4}^{2-}, \mathrm{NO}_{3}^{-}$and $\mathrm{NH}_{4}^{+}$. The concentrations of all these species in $\mu \mathrm{g} \mathrm{m}^{-3}$ are adopted.

\subsubsection{Visibility reconstruction by chemical components}

The mass scattering efficiency of spherical particles is a function of water and chemical components including $\left(\mathrm{NH}_{4}\right)_{2} \mathrm{SO}_{4}$, sea salt, mineral materials and carbonaceous species (Kimet al., 2001). To find which types of chemical components are the key for the visibility degradation during sampling period and how can the injection of FW particles change the visibility, the IMPROVE equation was used to calculate the light extinction coefficient $\left(b_{\text {ext }}\right)$ (Kim et al., 2001; Yang et al., 2007):

$$
\begin{aligned}
b_{\text {ext }} & =3 f(\mathrm{RH})[\text { ammonium sulfate }] \\
& +3 f(\mathrm{RH})[\text { ammonium nitrate }] \\
& +4[\mathrm{OM}]+1[\text { soil }]+10[\mathrm{BC}] .
\end{aligned}
$$

The visibility can be calculated by $\mathrm{Vs}=3.91 / b_{\text {ext }}$ (Yang et al., 2007). We used [ammonium sulfate $]=0.944 \times\left[\mathrm{NH}_{4}^{+}\right]+1.02 \times\left[\mathrm{SO}_{4}^{2-}\right], \quad$ [ammonium nitrate $]=1.29 \times\left[\mathrm{NO}_{3}^{-}\right],[\mathrm{OM}]=2.0 \times[\mathrm{OC}],[$ soil $]=\mathrm{MIN}$ and $[\mathrm{BC}]=[\mathrm{EC}]$ (Yang et al., 2007; Tao et al., 2009). $f(\mathrm{RH})$ is the $\mathrm{RH}$ growth function indicating how scattering efficiencies increase for $\mathrm{SO}_{4}^{2-}$ and $\mathrm{NO}_{3}^{-}$as they absorb liquid water and detailed data can be found in Tao et al. (2009).

\subsubsection{WRF-FLEXPART modeling}

To see the transport distance and decreasing trend of the highest mass concentrations of $\mathrm{PM}_{2.5}$ on CNY's Eve, Weather Research and Forecast model (WRF) version 3.4 was used to provide meteorological inputs of FLEXPART, with the (NCEP) National Center for Environmental Prediction global reanalysis meteorological data set $\left(1^{\circ} \times 1^{\circ}\right)$ as initial and boundary conditions. The time step is set as $180 \mathrm{~s}$. The grid system is divided into 28 layers in the vertical direction. Two domains are adopted, with the grid resolutions of 30 and $10 \mathrm{~km}$. The simulating time period is $02: 00-11: 00$ on 31 January 2014. The output of $10 \mathrm{~km}$ evolution wind farms is used as the input of FLEXPART. For forward simulating of FLEXPART model, Nanjing $\left(31^{\circ} 14^{\prime}-32^{\circ} 37^{\prime} \mathrm{N}, 118^{\circ} 22^{\prime}-\right.$ $119^{\circ} 14^{\prime} \mathrm{E}$, height as $50 \mathrm{~m}$ ) is considered as a whole source region. In this study, we only considered the dry and wet deposition of particles on CNY's Eve. The average mass concentration of $572 \mu \mathrm{g} \mathrm{m}^{-3}$ is used as the initial particle concentration.

\section{Results and discussion}

\subsection{Comparison of particles before, during and after the Chinese Spring Festival}

\subsubsection{PM $_{2.5}$ mass concentrations}

The concentrations of $\mathrm{PM}_{2.5}$ (averaged as $113 \pm 69 \mu \mathrm{g} \mathrm{m}^{-3}$, min-max: $21-318 \mu \mathrm{g} \mathrm{m}^{-3}$ ) in this study by filter sampling varied consistently with those for the nine online monitoring sites set by local government in urban Nanjing (averaged as $112 \pm 70 \mu \mathrm{g} \mathrm{m}^{-3}$, min-max: $13-385 \mu \mathrm{g} \mathrm{m}^{-3}$ ) (Fig. 2b). They correlated well with correlation coefficient $\left(R^{2}\right)$ higher than $0.95(P>0.01)$ (Supplement Fig. S6), indicating that a regional air pollution occurred in Nanjing (visibility $<10 \mathrm{~km}$ as Fig. 2a shown) during study period. The $\mathrm{PM}_{2.5}$ concentrations all peaked on CNY (30 January) and LF (14 February) and the peaking values on CNY were 4-5 times of the secondary standard of China National Ambient Air Quality ( $75 \mathrm{\mu g} \mathrm{m}^{-3}, 24 \mathrm{~h}$ average). Results suggested that FW have obvious impacts on fine particle pollution. On CNY's Eve, two massive FW events usually occur in the evening (around 19:00-20:00 $\mathrm{h}$ for the family reunion dinner) and midnight (00:00-02:00 $\mathrm{h}$ for celebrating the new year). $\mathrm{PM}_{2.5}$ showed the maximum concentrations for the two episodes as $426 \pm 236(20: 00 \mathrm{~h})$ and $572 \pm 136 \mu \mathrm{g} \mathrm{m}^{-3}(02: 00 \mathrm{~h})$, respectively (Fig.4). After 02:00, an obviously decreasing trend was pronounced as exponential form $\left(R^{2}=0.99\right)$. The concentrations decreased to $195 \pm 16 \mu \mathrm{g} \mathrm{m}^{-3}$ at 13:00, which was similar to that of $178 \pm 16 \mu \mathrm{g} \mathrm{m}^{-3}$ at 17:00, 30 January before extensively FW activities (Fig. 4). Note that on 30 and 31 January, the mixing layer heights were only 257 and 227 $\mathrm{m}$, the wind speeds were 1.7 and $2.1 \mathrm{~m} \mathrm{~s}^{-1}$ and the RH were 88 and $80 \%$, all favoring the accumulation of pollutants and 


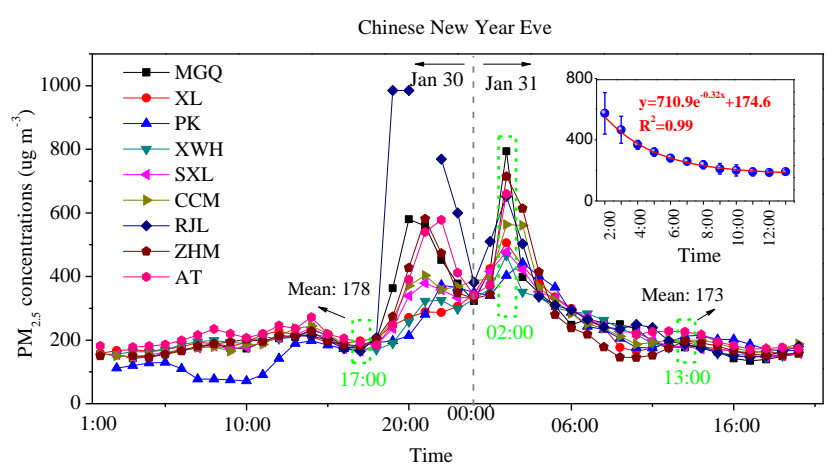

Figure 4. Hourly $\mathrm{PM}_{2.5}$ concentrations before, during and after Chinese New Year (CNY)'s Eve of 2014 in Nanjing. The figure at the top-right corner indicates the decreasing trend of averaged $\mathrm{PM}_{2.5}$ mass concentrations after 02:00 of CNY's Eve (on 30 January, 2014). Hourly data for the nine sites in urban Nanjing (locations were shown in supplement Fig. S4) were collected from the public platform at http://218.94.78.75/jsair/.

regional air pollution formation. It was verified by the WRFFLEXPART results which indicated that the particles with highest mass concentrations at 02:00 moved outside of Nanjing in the following $9 \mathrm{~h}$. The center with peaked particle mass concentrations transported about $285 \mathrm{~km}$ to the north of Nanjing (Supplement Fig. S7) and the decreasing trend was in accordance with the real particle concentrations decreasing (Fig.5). The injection of FW particles deteriorated the air quality, with visibilities decreasing to $1.4-6.2 \mathrm{~km}$ in the following 4 days. Therefore, the $\mathrm{PM}_{2.5}$ pollution raised by FW can last for about 4 days under unfavorable weather conditions (visibility was strongly related to $\mathrm{PM}_{2.5}$ mass in 30 January-3 February, $R^{2}=0.82$ ). On 3 and 5 February, $\mathrm{PM}_{2.5}$ was cleaned effectively by the rainfall (precipitation as 0.3 and $9 \mathrm{~mm}$ ), decreasing by 5.6-10.6 times for the 10 sites.

\subsubsection{Characterization of chemical species}

Tables 1 and 2 summarized the statistics of $\mathrm{PM}_{2.5}$, watersoluble ions, OC and EC before, during and after the SF. The data of CNY and LF were listed separately for intensive FW activities. The ratios of $\mathrm{PM}_{2.5}$ and chemical species on CNY and LF with those for the day before them were also listed. For elements, $\mathrm{K}, \mathrm{Si}, \mathrm{Al}, \mathrm{Na}, \mathrm{Ca}$ and $\mathrm{Fe}$ were the most abundant species, totally accounting for $85-90 \%$ of all the elements during these five periods. Without considering the data for CNY, elements $\mathrm{Al}, \mathrm{K}, \mathrm{Ba}$ and $\mathrm{Sr}$ at the SF still elevated when compared with those for pre-SF, whereas all other elements decreased during SF. This was related to the weakened sources, like construction activities, vehicle emission and industrial activities on the national holiday. For ions, $\mathrm{NO}_{3}^{-}$was most abundant, averaging as $5.9( \pm 3.7) \mu \mathrm{g} \mathrm{m}^{-3}$ for the days without intensive FW activities, then followed by $\mathrm{SO}_{4}^{2-}$ and $\mathrm{NH}_{4}^{+}$, with average concentrations of $5.0( \pm 3.7)$

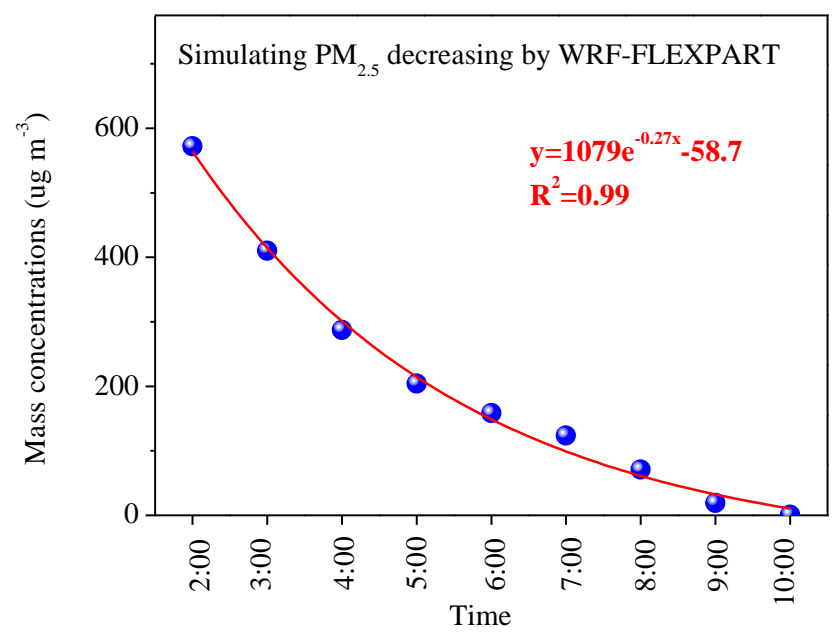

Figure 5. Particles decreasing trend on Chinese New Year's Eve by WRF-FLEXPART simulating. The particle concentrations decreased to $0.76 \mu \mathrm{g} \mathrm{m}^{-3}$ after $9 \mathrm{~h}$, faster than the real decrease as Fig. 4 shows. It can be explained as that we did not consider the injections of particles during simulating course, which biases the result.

and $4.8( \pm 2.4) \mu \mathrm{g} \mathrm{m}^{-3}$, respectively. $\mathrm{K}^{+}$and $\mathrm{Cl}^{-}$also had relatively high concentrations of $0.9( \pm 1.0)$ and $0.8( \pm 0.5)$ $\mu \mathrm{g} \mathrm{m}^{-3}$. It was similar to the results of Wang et al. (2014) that the secondary aerosols in Nanjing were dominated by nitrate in winter haze periods. $\mathrm{Na}^{+}, \mathrm{Ca}^{2+}, \mathrm{mg}^{2+}, \mathrm{F}^{-}$and $\mathrm{NO}_{2}^{-}$ accounted for a minor fraction (totally of $4.2 \%$ ). For carbonaceous species, OC3, OC4 and EC1 were most abundant, in combination accounting for $80 \%$ of the total carbon, indicating coal combustion and gasoline exhaust were important sources for $\mathrm{PM}_{2.5}$ Nanjing (Cao et al., 2005). OPC and $\mathrm{OC} 1$ also showed a higher values which may be related to biomass burning (Cao et al., 2005). $\mathrm{NO}_{3}^{-}$, OC and $\mathrm{EC}$ were highest for the pre-SF period, as the "spring travel rush" effect, characterized by extremely high traffic flows (Huang et al., 2012). The $\mathrm{PM}_{2.5}$ concentrations decreased for about $10 \mu \mathrm{g} \mathrm{m}^{-3}$ during SF, implying that the reduction of anthropogenic sources in this national holiday (Feng et al., 2012). The particle concentration lower than that for the pre-holiday period was also found in Shanghai (Huang et al., 2012).

During CNY with intensive FW, concentrations of $\mathrm{Ba}$ and $\mathrm{Sr}$ exhibited the most significant increase, by factors of 99.1 and 79.4 compared to the day before CNY (pre-CNY). Ba and $\mathrm{Sr}$ also showed the highest ratios for LF/pre-LF (the day before LF), as 9.7 and 5.7, respectively. Then followed by $\mathrm{EC} 2, \mathrm{OC} 1, \mathrm{~K}, \mathrm{~K}^{+}, \mathrm{Al}, \mathrm{Bi}, \mathrm{SO}_{4}^{2-}, \mathrm{OC} 2, \mathrm{EC} 1$ and $\mathrm{OC}$, going up to 4.1-37.7 times for CNY/pre-CNY, respectively. Other species increased by 1.2-3.8 times except for $\mathrm{W}(0.6), \mathrm{Na}^{+}$ (0.7), $\mathrm{NO}_{2}^{-}(0.8)$ and $\mathrm{OC} 4(0.9)$. It implied that $\mathrm{Na}^{+}$was not affected by the FW and can be used as the tracer of sea salt. Most species also increased during the LF when compared with pre-LF, but the increasing ratios were much lower 
than those on CNY. It can be explained by the FW activities during the LF (there are only organized FW activities by some organizations in cities) were less intensive than those on CNY (FW activities are national spread, from city to small villages). Crustal elements like $\mathrm{Li}, \mathrm{Be}, \mathrm{Si}, \mathrm{Na}, \mathrm{Ca}, \mathrm{Ti}$ and $\mathrm{Mn}$ increased by about 1-2 times during FW, indicating the use of clay in firework production. $\mathrm{Ca}^{2+}$ and $\mathrm{EC} 1$ decreased by factors of 0.8 and 0.9 , suggesting the increase of construction activities and vehicle emissions after SF. Meanwhile, Ba and Sr tend to be tracers of firework $\left(R^{2}=0.99\right)$, consistent with former studies (Estrellan and Iino, 2010; Sarkar et al., 2010; Feng et al., 2012). As shown in the Supplement Fig. S2 and literature (Moreno et al., 2007; Vecchi et al., 2008; Joly et al., 2010; Sarkar et al., 2010; Richard et al., 2011; Do et al., 2012; Tsai et al., 2012; Jing et al., 2014), the compounds of these elements are important $\mathrm{FW}$ manufacturing materials. Barium compounds can be used as oxidizers $\left(\mathrm{BaClO}_{3}\right.$ and $\left.\mathrm{Ba}\left(\mathrm{NO}_{3}\right)_{2}\right)$. $\mathrm{Sr}\left(\mathrm{NO}_{3}\right)_{2}$ can be used to give red color fireworks and potassium compounds are the most important compositions of black powder $\left(a \mathrm{KNO}_{3}\right.$ or $\mathrm{KClO}_{3}$ ). $\mathrm{Al}$ is used alone as a common constituent for fuel, or to form sparks and glitter effects or as alloy magnalium $(50: 50 \mathrm{Mg}: \mathrm{Al})$ for sparks and crackling stars. Fireworks also contain charcoal (Joly et al., 2010; Sarkar et al., 2010; Tsai et al., 2012) and organic materials are used as adhesive, such as polyvinyl alcohol, polyoxyethylene, phenol formaldehyde resin and shell-lac. They are responsible for the elevated concentrations of EC2 (Joly et al., 2010; Sarkar et al., 2010; Tsai et al., 2012) and OC1 during FW periods.

\subsection{Mass closure and reconstruction of visibility}

Figure 6 illustrates the $\mathrm{PM}_{2.5}$ mass balance of MIN, TE, OM, EC, SS, SIA and UM. About $60 \%$ of the chemical species in $\mathrm{PM}_{2.5}$ were detected. The unaccounted PM mass were explained by the following four reasons: (1) non-C atoms in organic aerosols; (2) sampling and measurement artifacts; (3) conversion factors used for OM and MIN calculating; (4) aerosol water content (Tsyro, 2005; Terzi et al., 2010). Water constituted $20-35 \%$ of the annual mean $\mathrm{PM}_{10}$ and $\mathrm{PM}_{2.5}$ concentrations (Tsyro, 2005). On 6 February, the water content in $\mathrm{PM}_{2.5}$ was high to $72 \%$, indicating the influence of rainfall and high RH $(90 \%)$. These also lead to the gravimetrically measured particulate mass $\left(\mathrm{PM}_{\text {meas }}\right)$ higher than the mass calculated by adding individual components $\left(\mathrm{PM}_{\text {meas }}\right)$, while tight correlations still existed between them $\left(\mathrm{PM}_{\text {meas }}=\right.$ $\left.1.52 \mathrm{PM}_{\mathrm{cal}}+14.5, R^{2}=0.91\right)$. The slope was similar to those as 1.02-1.42 in Terzi et al. (2010).

The averaged chemical components of $\mathrm{PM}_{2.5}$ profiles exhibited OM $(26 \%)>$ SIA $(18 \%)>$ MIN $(9 \%)>$ EC $(3.9 \%)>\mathrm{SS}(1.7 \%)>\mathrm{TE}(0.67 \%)$. The mass percentages of OM, TE and EC decreased in the SF (as 23, 0.6 and $2.7 \%$ ) when compared with those at the pre-SF (as 34, 0.7 and $6.2 \%$ ). These changes reflected the holiday effect; i.e., at the SF holiday, the new injection of FW particles can-
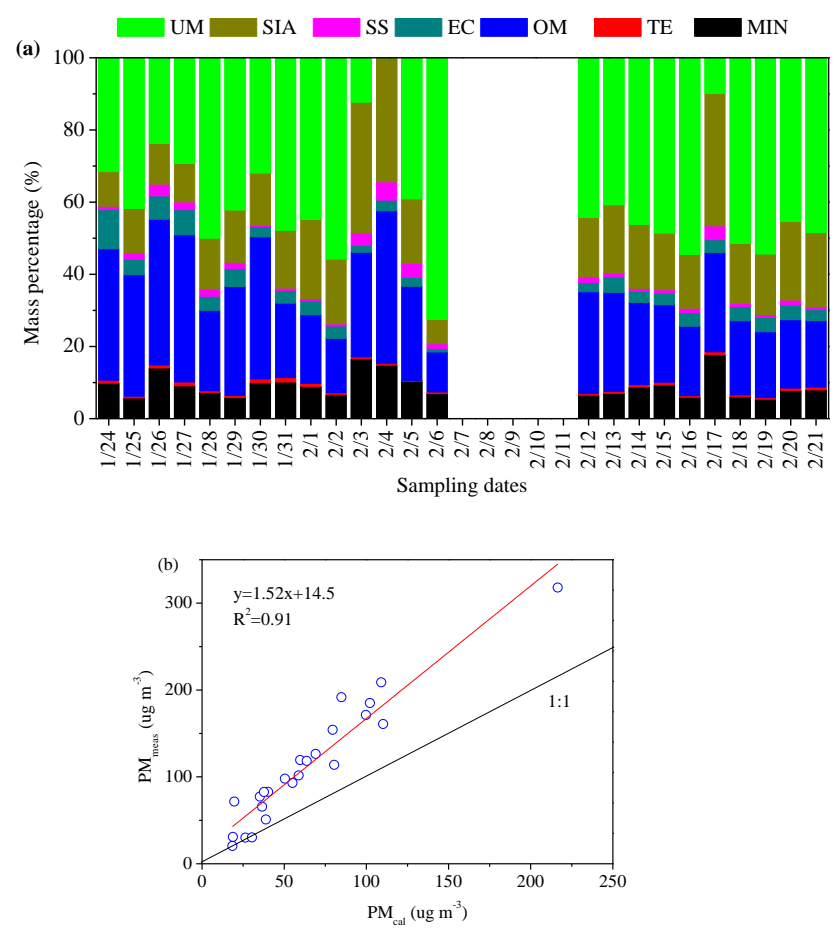

Figure 6. Mass balance of chemical species in $\mathrm{PM}_{2.5}$ during sampling periods (a) and relationship between the mass calculated by adding individual components and the gravimetrically measured particulate mass (b). $\mathrm{MIN}=2.14 \times \mathrm{Si}+1.67 \times \mathrm{Ti}+1.89 \times \mathrm{Al}+1.59 \times$ $\mathrm{Mn}+1.67 \times \mathrm{Mg}+1.95 \times \mathrm{Ca}+1.35 \times \mathrm{Na}+1.21 \times \mathrm{K}+1.43 \times \mathrm{Fe}$. Trace elements (TE) indicated the sum of all other elements except for those used in calculating MIN. Sea salt $(\mathrm{SS})=\left[\mathrm{Na}^{+}\right]+$ $\left[\mathrm{ss}^{-\mathrm{Cl}^{-}}\right]+\left[\mathrm{ss}^{-\mathrm{Mg}^{2+}}\right]+\left[\mathrm{ss}-\mathrm{K}^{-}\right]+\left[\mathrm{ss}^{-\mathrm{Ca}^{2+}}\right]+\left[\mathrm{ss}^{2} \mathrm{SO}_{4}^{2-}\right] ; \mathrm{ss}^{-} \mathrm{Cl}^{-}=$ $1.8 \times\left[\mathrm{Na}^{+}\right] ; \quad$ ss $-\mathrm{Mg}^{2+}=0.12 \times\left[\mathrm{Na}^{+}\right] ;$ss- $\mathrm{K}^{-}=0.036 \times\left[\mathrm{Na}^{+}\right]$; ss-Ca ${ }^{2+}=0.038 \times\left[\mathrm{Na}^{+}\right]$; ss- $\mathrm{SO}_{4}^{2-}=0.252 \times\left[\mathrm{Na}^{+}\right]$. Secondary inorganic aerosol (SIA) was calculated as the sum of nss- $\mathrm{SO}_{4}^{2-}$, $\mathrm{NO}_{3}^{-}$and $\mathrm{NH}_{4}^{+}$. Organic matter $(\mathrm{OM})=2.0 \times \mathrm{OC}$. UM indicated unidentified matter. 30 January -7 February represents the Chinese Spring Festival in 2014; 30 January is the Chinese New Year day; 14 February is the Lantern Festival day.

not offset the reduced particles from vehicle emission and/or to industrial sources, especially for organic matter, trace elements and elemental carbon, which are important compositions of vehicle exhausts and industrial activities. On CNY, obviously elevated OM was observed, accounting for $39.3 \%$ of $\mathrm{PM}_{2.5}$. While SIA was only $14.4 \%$, with the peak values occurred on 3 February (as 36\%), suggesting that after intensive emission of FW pollutants on CNY's Eve, secondary ions were gradually formed during aging processes through gas-particles transformation of $\mathrm{SO}_{2}$ and $\mathrm{NO}_{\mathrm{x}}$, etc. It should be emphasized that MIN and TE were both important components of $\mathrm{PM}_{2.5}$, totally accounting for 5.8-18.5\%. In a recent study by Aerosol Mass Spectrometer (AMS) for aerosols during the Chinese Spring Festival in Beijing, organics, nitrate, sulfate, ammonium, BC and chloride, accounted for 43 , 
Table 1. Mass concentrations of elements in $\mathrm{PM}_{2.5}$ before, during and after the 2014 Chinese Spring Festival in Nanjing (ng $\mathrm{m}^{-3}$ ).

\begin{tabular}{|c|c|c|c|c|c|c|c|}
\hline Elements & Pre-SF & SF (without CNY) & After-SF (without LF) & $\mathrm{CNY}$ & $\mathrm{LF}$ & $\mathrm{CNY} /$ pre-CNY & $\mathrm{LF} /$ pre-LF \\
\hline $\mathrm{Li}$ & $1.9 \pm 0.7$ & $1.1 \pm 0.8$ & $1.4 \pm 1.0$ & 2.3 & 1.4 & 1.8 & 1.3 \\
\hline $\mathrm{Be}$ & $0.1 \pm 0.0$ & $0.0 \pm 0.0$ & $0.0 \pm 0.0$ & 0.0 & 0.0 & 2.1 & 1.9 \\
\hline $\mathrm{Na}$ & $826 \pm 209$ & $417 \pm 196$ & $435 \pm 172$ & 563 & 506 & 1.3 & 1.1 \\
\hline $\mathrm{Mg}$ & $124 \pm 79$ & $97 \pm 89$ & $106 \pm 30$ & 196 & 124 & 2.6 & 1.3 \\
\hline $\mathrm{Al}$ & $612 \pm 234$ & $802 \pm 550$ & $530 \pm 230$ & 3127 & 811 & 7.9 & 1.7 \\
\hline $\mathrm{Si}$ & $1105 \pm 420$ & $752 \pm 147$ & $847 \pm 422$ & 1431 & 943 & 2.3 & 1.4 \\
\hline $\mathrm{P}$ & $66 \pm 35$ & $35 \pm 20$ & $29 \pm 13$ & 42 & 35 & 1.5 & 1.3 \\
\hline $\mathrm{K}$ & $1940 \pm 725$ & $3330 \pm 3848$ & $1276 \pm 817$ & 14336 & 2940 & 9.3 & 1.8 \\
\hline $\mathrm{Ca}$ & $454 \pm 198$ & $355 \pm 95$ & $383 \pm 193$ & 454 & 469 & 1.9 & 1.6 \\
\hline $\mathrm{Sc}$ & $0.1 \pm 0.0$ & $0.1 \pm 0.0$ & $0.1 \pm 0.1$ & 0.1 & 0.1 & 1.5 & 1.4 \\
\hline $\mathrm{Ti}$ & $31 \pm 27$ & $14 \pm 8$ & $24 \pm 28$ & 20 & 15 & 1.2 & 1.7 \\
\hline $\mathrm{V}$ & $7.7 \pm 2.3$ & $7.0 \pm 7.8$ & $6.6 \pm 4.6$ & 9.4 & 10.5 & 1.2 & 2.4 \\
\hline $\mathrm{Cr}$ & $10.4 \pm 4.0$ & $7.9 \pm 5.7$ & $8.7 \pm 3.4$ & 17.4 & 10.2 & 2.9 & 1.3 \\
\hline $\mathrm{Mn}$ & $48 \pm 22$ & $22 \pm 19$ & $67 \pm 67$ & 47 & 50 & 1.9 & 1.3 \\
\hline $\mathrm{Fe}$ & $385 \pm 342$ & $160 \pm 140$ & $261 \pm 172$ & 304 & 300 & 1.8 & 1.9 \\
\hline Co & $0.4 \pm 0.1$ & $0.4 \pm 0.4$ & $0.4 \pm 0.2$ & 0.6 & 0.5 & 2.6 & 1.6 \\
\hline $\mathrm{Ni}$ & $8.5 \pm 6.0$ & $4.5 \pm 3.1$ & $8.9 \pm 5.6$ & 5.9 & 7.6 & 1.3 & 1.5 \\
\hline $\mathrm{Cu}$ & $102 \pm 30$ & $81 \pm 63$ & $77 \pm 25$ & 170 & 116 & 1.3 & 1.3 \\
\hline $\mathrm{Zn}$ & $257 \pm 145$ & $93 \pm 81$ & $194 \pm 154$ & 242 & 174 & 1.6 & 1.3 \\
\hline As & $17 \pm 13$ & $9.0 \pm 9.8$ & $8.0 \pm 4.6$ & 22 & 8.8 & 2.2 & 1.3 \\
\hline $\mathrm{Rb}$ & $8.5 \pm 2.2$ & $4.7 \pm 4.2$ & $5.7 \pm 4.5$ & 12 & 6.5 & 1.7 & 1.5 \\
\hline $\mathrm{Sr}$ & $5.1 \pm 3.9$ & $34 \pm 49$ & $4.9 \pm 5.9$ & 181 & 20.5 & 79.4 & 5.7 \\
\hline $\mathrm{Y}$ & $0.2 \pm 0.1$ & $0.1 \pm 0.1$ & $0.2 \pm 0.1$ & 0.1 & 0.2 & 1.5 & 1.5 \\
\hline $\mathrm{Zr}$ & $1.9 \pm 0.7$ & $1.6 \pm 0.6$ & $1.9 \pm 1.3$ & 1.6 & 2.3 & 1.2 & 1.4 \\
\hline Mo & $2.7 \pm 1.0$ & $1.3 \pm 1.2$ & $2.9 \pm 1.8$ & 2.8 & 2.7 & 1.6 & 0.6 \\
\hline $\mathrm{Cd}$ & $3.4 \pm 2.8$ & $1.3 \pm 1.4$ & $1.1 \pm 0.7$ & 4.1 & 1.3 & 1.7 & 1.3 \\
\hline $\mathrm{Sn}$ & $9.0 \pm 5.6$ & $5.0 \pm 6.1$ & $4.6 \pm 3.5$ & 18.0 & 4.5 & 3.7 & 1.1 \\
\hline $\mathrm{Sb}$ & $11 \pm 6.5$ & $4.8 \pm 5.4$ & $3.0 \pm 1.6$ & 13.9 & 4.8 & 2.9 & 1.7 \\
\hline Cs & $1.8 \pm 1.0$ & $0.7 \pm 0.8$ & $1.4 \pm 1.5$ & 1.9 & 1.2 & 1.4 & 1.4 \\
\hline $\mathrm{Ba}$ & $14 \pm 12$ & $152 \pm 216$ & $14.4 \pm 20.4$ & 850 & 70.1 & 99.1 & 9.7 \\
\hline $\mathrm{La}$ & $0.7 \pm 0.6$ & $0.6 \pm 0.5$ & $0.6 \pm 0.5$ & 0.6 & 0.5 & 2.5 & 0.8 \\
\hline $\mathrm{Ce}$ & $0.8 \pm 0.5$ & $0.4 \pm 0.3$ & $0.6 \pm 0.6$ & 0.6 & 0.5 & 2.3 & 1.0 \\
\hline $\mathrm{Sm}$ & $0.1 \pm 0.0$ & $0.0 \pm 0.0$ & $0.0 \pm 0.0$ & 0.0 & 0.0 & 1.4 & 1.2 \\
\hline W & $4.3 \pm 2.4$ & $3.1 \pm 2.9$ & $3.2 \pm 1.3$ & 4.7 & 5.4 & 0.6 & 1.1 \\
\hline $\mathrm{Tl}$ & $1.4 \pm 0.7$ & $0.5 \pm 0.5$ & $0.8 \pm 0.5$ & 1.4 & 0.8 & 1.4 & 1.2 \\
\hline $\mathrm{Pb}$ & $187 \pm 96$ & $116 \pm 132$ & $91 \pm 54$ & 425 & 127 & 2.6 & 1.0 \\
\hline $\mathrm{Bi}$ & $7.3 \pm 5.4$ & $9.1 \pm 13.0$ & $3.0 \pm 2.2$ & 36.9 & 6.5 & 7.2 & 2.3 \\
\hline Th & $0.6 \pm 0.0$ & $0.5 \pm 0.0$ & $0.6 \pm 0.0$ & 0.6 & 0.6 & 1.0 & 1.0 \\
\hline $\mathrm{U}$ & $0.1 \pm 0.0$ & $0.0 \pm 0.0$ & $0.1 \pm 0.1$ & 0.1 & 0.1 & 1.4 & 1.2 \\
\hline
\end{tabular}

Pre-SF indicated the period before the 2014 Chinese Spring Festival (SF), covering the days from 24 to 29 January; SF indicated the Spring Festival period, covering the days from 30 January to 6 February; after-SF indicated the period after Spring Festival, covering the days from 12 to 21 February. CNY indicates the Chinese New Year (CNY) day and in 2014, it is 30 January; pre-CNY is the day before CNY and is 29 January. LF indicates the Lantern Festival (LF) day and in 2014, it is 14 February; pre-LF is the day before LF and is 14 Febraury. On CNY and LF, intensive fireworks were burned. Therefore, the mass concentrations of PM 2.5 and associated chemical species of the 2 days were listed separately. CNY/pre-CNY indicates the ratios between mass concentrations of $\mathrm{PM}_{2.5}$ and associated chemical species on CNY and the day before CNY (pre-CNY). $\mathrm{LF} /$ pre-LF indicates the ratios between mass concentrations of $\mathrm{PM}_{2.5}$ and associated chemical species at the LF and the day before the LF (pre-LF).

$2214,13,5$ and $3 \%$ of $\mathrm{PM}_{1.0}$ with no elements considered (Jiang et al., 2014). The combination of filter-sampling offline chemical analysis and online real-time monitoring of chemical species are desired for atmospheric aerosol studies.

Figure $7 \mathrm{a}$ shows the calculated average values of extinction coefficient $\left(b_{\text {ext }}\right)$. They varied between 44 and $525 \mathrm{Mm}^{-1}$. The calculated visibility $\left(V_{\text {cal }}\right)$ exhibited good correlations with the measured one $\left(V_{\text {meas }}\right)\left(V_{\text {cal }}=\right.$ $\left.0.96 V_{\text {meas }}+1.4, R^{2}=0.45, P<0.001\right)$. The discrepancy be- tween the measured and calculated values can be attributed to the influence of ambient water vapor (Huang et al., 2012), which was a key component of aerosol particles in this study as discussed before. At higher RH, the role of ambient water vapor on light extinction was more important (Huang et al., 2012). The $b_{\text {ext }}$ exhibited higher values on CNY and the following 3 days, in the range of $301-525 \mathrm{Mm}^{-1}$. $\left(\mathrm{NH}_{4}\right)_{2} \mathrm{SO}_{4}$ had the largest contribution to $b_{\text {ext }}$, accounting for $36.5 \pm 11.7 \%$, followed by $\mathrm{NH}_{4} \mathrm{NO}_{3}(25.8 \pm 8.2 \%)$, 
Table 2. Mass concentrations of ions and carbonaceous species in $\mathrm{PM}_{2.5}$ before, during and after the 2014 Chinese Spring Festival in Nanjing $\left(\mu \mathrm{g} \mathrm{m}^{-3}\right)$.

\begin{tabular}{|c|c|c|c|c|c|c|c|}
\hline Elements & Pre-SF & SF (without CNY) & After-SF (without LF) & $\mathrm{CNY}$ & $\mathrm{LF}$ & $\mathrm{CNY} /$ pre-CNY & $\mathrm{LF} /$ pre-LF \\
\hline $\mathrm{Na}^{+}$ & $0.65 \pm 0.17$ & $0.37 \pm 0.07$ & $0.31 \pm 0.09$ & 0.40 & 0.29 & 0.7 & 1.0 \\
\hline $\mathrm{NH}_{4}^{+}$ & $4.26 \pm 1.12$ & $4.81 \pm 3.68$ & $5.33 \pm 1.98$ & 10.5 & 6.85 & 2.4 & 1.3 \\
\hline $\mathrm{K}^{+}$ & $0.49 \pm 0.31$ & $1.59 \pm 1.55$ & $0.67 \pm 0.22$ & 4.81 & 1.06 & 8.9 & 1.8 \\
\hline $\mathrm{Ca}^{2+}$ & $0.09 \pm 0.05$ & $0.23 \pm 0.14$ & $0.19 \pm 0.09$ & 0.25 & 0.18 & 3.3 & 0.8 \\
\hline $\mathrm{Mg}^{2+}$ & $0.03 \pm 0.03$ & $0.20 \pm 0.31$ & $0.08 \pm 0.04$ & 0.10 & 0.09 & 1.3 & 1.5 \\
\hline $\mathrm{F}^{-}$ & $0.03 \pm 0.01$ & $0.04 \pm 0.02$ & $0.03 \pm 0.01$ & 0.05 & 0.04 & 2.2 & 1.4 \\
\hline $\mathrm{Cl}^{-}$ & $1.16 \pm 0.26$ & $0.72 \pm 0.54$ & $0.75 \pm 0.40$ & 3.04 & 1.09 & 3.8 & 1.2 \\
\hline $\mathrm{NO}_{2}^{-}$ & $0.02 \pm 0.01$ & $0.04 \pm 0.01$ & $0.04 \pm 0.01$ & 0.02 & 0.05 & 0.8 & 1.7 \\
\hline $\mathrm{NO}_{3}^{-}$ & $5.81 \pm 2.54$ & $5.27 \pm 5.38$ & $6.59 \pm 2.98$ & 14.6 & 8.36 & 2.5 & 1.3 \\
\hline $\mathrm{SO}_{4}^{2-}$ & $3.46 \pm 1.28$ & $7.74 \pm 5.17$ & $4.05 \pm 2.34$ & 16.1 & 4.54 & 4.4 & 1.1 \\
\hline OC & $18.2 \pm 7.45$ & $9.38 \pm 6.70$ & $8.95 \pm 3.15$ & 56.9 & 12.2 & 4.1 & 1.1 \\
\hline $\mathrm{EC}$ & $6.93 \pm 4.64$ & $3.12 \pm 3.06$ & $2.96 \pm 1.20$ & 8.29 & 3.38 & 1.8 & 0.9 \\
\hline $\mathrm{OC} 1$ & $1.87 \pm 1.40$ & $0.40 \pm 0.23$ & $0.50 \pm 0.16$ & 16.1 & 0.64 & 33.2 & 1.1 \\
\hline OC2 & $4.32 \pm 1.65$ & $2.56 \pm 1.75$ & $2.36 \pm 0.74$ & 14.8 & 2.86 & 4.2 & 1.1 \\
\hline OC3 & $5.46 \pm 2.69$ & $2.77 \pm 2.09$ & $2.90 \pm 1.15$ & 9.10 & 4.28 & 2.4 & 1.0 \\
\hline OC4 & $5.44 \pm 1.52$ & $3.27 \pm 3.03$ & $2.94 \pm 1.36$ & 5.81 & 4.46 & 0.9 & 1.1 \\
\hline EC1 & $7.92 \pm 5.07$ & $3.44 \pm 2.64$ & $3.15 \pm 1.00$ & 18.8 & 3.30 & 4.1 & 0.9 \\
\hline $\mathrm{EC} 2$ & $0.12 \pm 0.07$ & $0.07 \pm 0.06$ & $0.06 \pm 0.05$ & 0.50 & 0.08 & 37.7 & 1.6 \\
\hline EC3 & $0.00 \pm 0.00$ & $0.00 \pm 0.00$ & $0.00 \pm 0.00$ & 0.11 & 0.00 & - & - \\
\hline OPC & $1.12 \pm 2.43$ & $0.39 \pm 0.39$ & $0.24 \pm 0.43$ & 11.09 & 0.00 & - & - \\
\hline $\mathrm{PM}_{2.5}$ & $119.6 \pm 43.4$ & $106.9 \pm 84.1$ & $88.9 \pm 37.4$ & 318.0 & 118.4 & 3.1 & 1.3 \\
\hline
\end{tabular}

- Not detected in the day before CNY and LF.

Pre-SF indicated the period before the 2014 Chinese Spring Festival (SF), covering the days from 24 to 29 January; SF indicated the Spring Festival period, covering the days from 30 January to 6 February; after-SF indicated the period after the Spring Festival, covering the days from 12 to 21 February. CNY indicates the Chinese New Year (CNY) day and in 2014, it is 30 January; pre-CNY is the day before CNY and is 29 January. LF indicates the Lantern Festival (LF) day and in 2014, it is 14 February; pre-LF is the day before LF and is 14 February. On CNY and LF, intensive fireworks were burned. Therefore, the mass concentrations of PM 2.5 and associated chemical species of the 2 days were listed separately. CNY/pre-CNY indicates the ratios between mass concentrations of $\mathrm{PM}_{2.5}$ and associated chemical species on CNY and the day before $\mathrm{CNY}$ (pre-CNY).

$\mathrm{LF} /$ pre-LF indicates the ratios between mass concentrations of $\mathrm{PM}_{2.5}$ and associated chemical species during the LF and the day before LF (pre-LF).

EC $(21.8 \pm 9.0 \%), \mathrm{OM}(10.8 \pm 4.2 \%)$ and soil $(5.1 \pm 1.8 \%)$ (Fig. 7b). These results implied that sulfate was the largest contributor to visibility degradation especially during the SF period. Before SF, the contribution of EC can be as high as $34-44 \%$ during serious haze periods (24-26 January, $\mathrm{RH}<51 \%$ ). It highlights the importance of controlling vehicle emissions in haze days. Sulfate and soot were also found as the main contributors to visibility degradation in other studies (Tao et al., 2009). The results obtained here were different from those in Shanghai that organic aerosol had the largest contribution to the aerosol extinction as $47 \%$, then followed by ammonium sulfate ( $22 \%)$, ammonium nitrate (14\%) and EC (12\%) (Huang et al., 2012). The FW on CNY obviously changed the contributions of chemical species to scattering coefficient. On CNY, the influence of FW particles on visibility was mainly controlled by $\left(\mathrm{NH}_{4}\right)_{2} \mathrm{SO}_{4}(36 \%)$, $\mathrm{NH}_{4} \mathrm{NO}_{3}(26 \%)$, EC (15\%) and OM (15\%). During FW particle aging processes, the contribution of $\left(\mathrm{NH}_{4}\right)_{2} \mathrm{SO}_{4}$ increased from $36 \%$ (30 January) to $67 \%$ ( 3 February), while for $\mathrm{NH}_{4} \mathrm{NO}_{3}$, its contribution increased first to $28 \%$ on 31 January and then decreased to $10 \%$ (3 February). Similar trend was found for EC, it increased to $22 \%$ (1 February) and then decreased to $7.6 \%$ ( 3 February). For OM, it ex- hibited decreasing trend, to the lowest value on 2 February $(5.5 \%)$.

\subsection{Source evolution}

\subsubsection{Contributions of firework burning to $\mathbf{P M}_{2.5}$ on CNY and LF}

The $\mathrm{PM}_{2.5}$ concentrations peaked on CNY and LF in this study with intensive $\mathrm{FW}$ activities. Assuming that the $\mathrm{PM}_{2.5}$ collected on CNY and LF was a simple combination of particles from FW and other emission sources, the contribution and compositions of the particles from FW can be estimated by subtracting the contribution of the non-firework sources (Feng et al., 2012). An accumulation factor of 0.88 (mixing layer heights on 29 and 30 January and were 227 and $257 \mathrm{~m}$, respectively) and 0.51 (mixing layer heights on 13 and 14 February were 353 and $696 \mathrm{~m}$, respectively) were used to eliminate the disperse impact caused by mixing height layer increasing (Feng et al., 2012; Deka and Hoque, 2014). About $60.1 \%$ and $10.9 \%$ of the $\mathrm{PM}_{2.5}$ masses on CNY and LF were estimated to be from FW. The contributions to almost all species of $\mathrm{FW}$ on $\mathrm{CNY}$ were more obvious than those during LF (Fig. 8). On CNY, OPC, EC3, Ba, Sr, Soot-EC, 

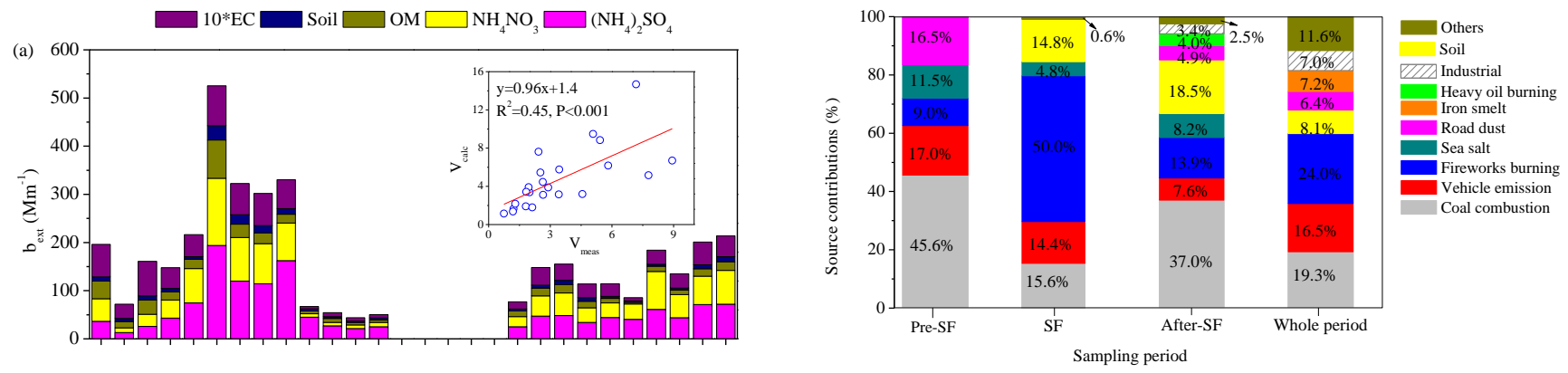

Figure 9. Source contributions to atmospheric $\mathrm{PM}_{2.5}$ before, during, after the 2014 Spring Festival (SF) and the whole period by principal component analysis. pre-SF indicated the period before SF, covering the days from 24 to 29 January; SF indicated the period during SF, covering the days from 30 January to 6 February; after-SF indicated the period after SF, covering the days from 12 to 21 February. The whole period included pre-SF, SF and after-SF period.

\subsubsection{Source variations by tracers and PCA analysis}

In order to further identify the sources of particles, PCA results are shown in Fig. 9 and Supplement Fig. S8.

Respectively, five, five and eight factors were extracted

Figure 7. Extinction coefficients of chemical components in $\mathrm{PM}_{2.5}$ in Nanjing (a) and relative contribution to light extinction of chemical components in $\mathrm{PM}_{2.5}$ (b). 30 January-7 February belongs to the Chinese Spring Festival in 2014; 30 January is the Chinese New Year day; 14 February is the Lantern Festival day. $V_{\text {cal }}$ indicates the visibility calculated by adding individual components; $V_{\text {meas }}$ is the measured visibility.

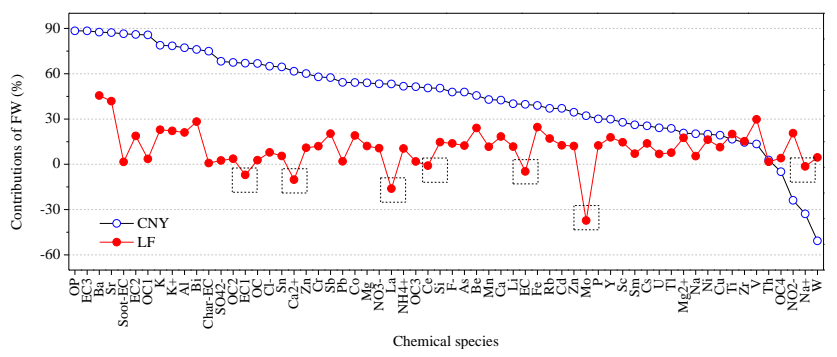

Figure 8. Contributions of firework burning (FW) on CNY and LF to chemical species in $\mathrm{PM}_{2.5}$. CNY means Chinese New Year day (30 January); LF means Lantern Festival day (14 February).

$\mathrm{EC} 2$ and $\mathrm{OC} 1$ maintained the higher contributions from $\mathrm{FW}$, larger than $80 \%$, followed by $\mathrm{K}, \mathrm{K}^{+}, \mathrm{Al}$, Bi and Char-EC, with the contributions higher than $70 \%$. During the LF, $45 \%$ of $\mathrm{Ba}$ and $41 \%$ of $\mathrm{Sr}$ were from $\mathrm{FW}$ and the contributions to $\mathrm{V}, \mathrm{Bi}, \mathrm{Fe}, \mathrm{Be}, \mathrm{K}, \mathrm{K}^{+}, \mathrm{Al}, \mathrm{NO}_{2}^{-}$and $\mathrm{Sb}$ were higher than $20 \%$. for the data set of pre-SF, SF and after-SF period, which explained 100, 99.4 and $97.5 \%$ of the variance, suggesting almost all the sources have been explained. Firework burning was the most important source for $\mathrm{PM}_{2.5}$, contributing $24.0 \%$ for the whole period. Coal combustion (including both local and regional transport) was also important to $\mathrm{PM}_{2.5}$ at this site in winter (contributing 19.3\%). It was verified by the time series of tracers (As and Sb, highly correlated with $R^{2}=0.88$ ) for coal combustion in Fig. 10a. Extremely high values can be found on 24 January, even higher than those for the intensive FW day. This can be explained by two reasons: (1) on 24 January, it was a haze day with visibility and mixing layer height as $8.2 \mathrm{~km}$ and $321 \mathrm{~m}$, facilitating the accumulation of pollutants; (2) the air masses on 24 January were classified as cluster 2 from central China where the Chang-Zhu-Tan region with intensive non-ferrous metal metallurgy industries with huge coal consumption is located. On this day, higher concentrations were also found for metals like $\mathrm{Mg}\left(228 \mathrm{ng} \mathrm{m}^{-3}\right), \mathrm{Cr}\left(17 \mathrm{ng} \mathrm{m}^{-3}\right), \mathrm{Ca}\left(782 \mathrm{ng} \mathrm{m}^{-3}\right)$, Mn $\left(85 \mathrm{ng} \mathrm{m}^{-3}\right)$, Fe $\left(1014 \mathrm{ng} \mathrm{m}^{-3}\right)$, Co $\left(0.61 \mathrm{ng} \mathrm{m}^{-3}\right)$, $\mathrm{Ni}\left(7.6 \mathrm{ng} \mathrm{m}^{-3}\right), \mathrm{Cu}\left(124 \mathrm{ng} \mathrm{m}^{-3}\right)$, Mo $\left(4.4 \mathrm{ng} \mathrm{m}^{-3}\right), \mathrm{Cd}$ $\left(8.8 \mathrm{ng} \mathrm{m}^{-3}\right)$, Sn $\left(16 \mathrm{ng} \mathrm{m}^{-3}\right)$ and $\mathrm{Pb}\left(359 \mathrm{ng} \mathrm{m}^{-3}\right)$. FW contributed about half of the $\mathrm{PM}_{2.5}$ during SF period. For pre-SF and after-SF periods, its contributions were 9 and $14 \%$. As shown in Fig. 10b, the tracers of $\mathrm{Ba}$ and $\mathrm{Sr}$ exhibited much higher values at the SF, and there were also some small peaks before SF (27 January) and after SF (14 February). During the week-long holiday, most industrial activities shut down in China with low energy consumption during this period (Feng et al., 2012; Huang et al., 2012; Li et al., 2013). As holiday 


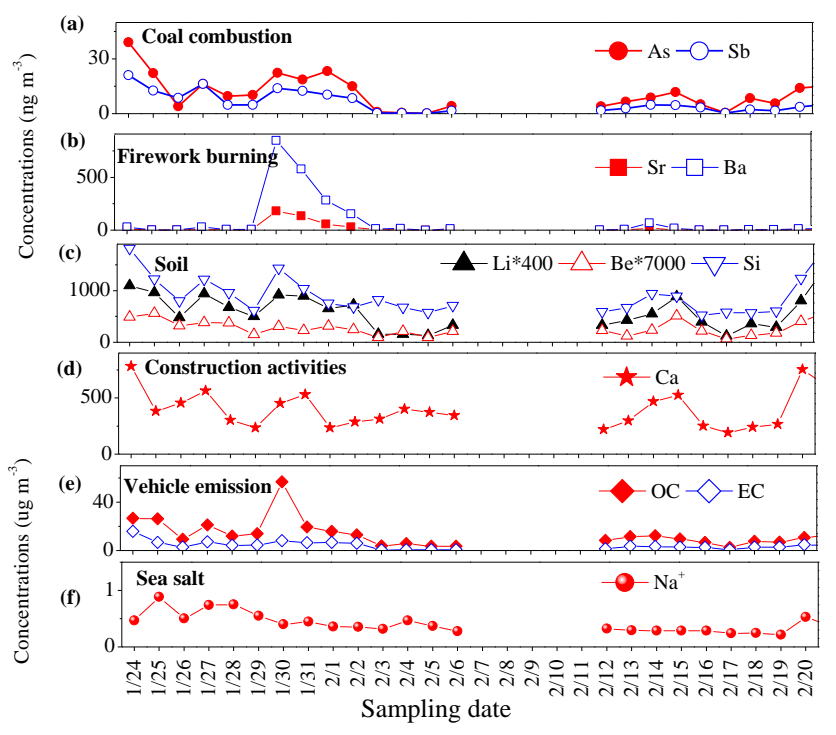

Figure 10. Time series of tracers for (a) coal combustion, (b) firework burning, (c) soil, (d) construction activities or road dust, (e) vehicle emission and (f) sea salt. The $y$ axis units for (a), (b), (c) and (d) are $\mathrm{ng} \mathrm{m}^{-3}$ and are ug $\mathrm{m}^{-3}$ for (e) and (f). 30 January-7 February belongs to the Chinese Spring Festival in 2014; 30 January is the Chinese New Year day; 14 February is the Lantern Festival day.

effect, when compared the source contributions at the SF to those at the pre-SF, the contributions of coal combustion decreased from 46 to only $16 \%$, the contributions of vehicle emissions decreased from 17 to $14 \%$ and the contributions of dust also decreased. For the after-SF period, along with the gradual restarting of industrial/construction activities and the increasing of traffic flows, the source contributions of coal combustion, heavy oil burning, industrial processes and road dust increased, to $37,4,3.4$ and $5 \%$, respectively. OC and $\mathrm{EC}$ were selected as the tracers of vehicle emission and their correlation was higher to 0.80 without the data on $\mathrm{CNY}$ and LF. Ca was selected as the tracer for construction activities or road dust (the main road was covered by abundant dust from subway construction). $\mathrm{Na}^{+}$was used as the tracer of sea salt. $\mathrm{Li}, \mathrm{Be}$ and $\mathrm{Si}$ were selected as the indicators of soil ( $R^{2}$ higher than 0.65 between them). The variations of mass concentrations of these tracers before, during and after the SF coincided with the contributions of corresponding sources.

\subsection{Aging processes}

\subsubsection{The aging processes and mechanisms of firework-burning particles}

Previous studies indicated that the aerosol emission from FW activities is a short-term air quality degradation event (Jing et al., 2014), but no studies were concerned with how long the duration time is, or with what the substantial hazard risk levels raised by elevated heavy metals from intensive FW are during the aging processes. To better understand the influence of FW particles, its aging processes after emission were analyzed. It should be emphasized that during SF, contributions from other human sources were low (Fig. 9), so the air quality in these days was mainly influenced by the highest contributor-FW particles' aging processes, including deposition, dispersion and transformations.

From Figs. $2 b$ and 10b, it can be seen that it takes abut 4 days for the highest $\mathrm{PM}_{2.5}$ and FW tracers-Ba and Sr on CNY to step down to the normal values of pre-CNY. The same situations were found for $\mathrm{K}^{+}, \mathrm{Cl}^{-}, \mathrm{NH}_{4}^{+}$and $\mathrm{NO}_{3}^{-}$(Fig. 11a). For $\mathrm{SO}_{4}^{2-}$, on 3 February, its mass concentrations decreased to a lower level of $6.1 \mu \mathrm{g} \mathrm{m}^{-3}$. Then on 4 February, it did not decrease immediately to the level of 29 January until a rainfall $(9 \mathrm{~mm})$ on 5 February. New emissions related with scattered firework burning at surrounding areas were thought to be introduced on 4 February as $\mathrm{Ba}, \mathrm{Sr}, \mathrm{K}^{+}, \mathrm{Ca}^{2+}, \mathrm{Ca}$ and $\mathrm{Na}^{+}$(they are all from primary emissions) slightly increased on 4 February. Therefore, the variations of $\mathrm{SO}_{4}^{2-}$ on 5 February may not just related with the aging of the intensive FW particles on CNY's Eve. On 1 February, though $\mathrm{PM}_{2.5}$ has decreased from 317 to $185 \mu \mathrm{g} \mathrm{m}^{-3}$, the visibility was still low as $2.2 \mathrm{~km}$, with peak concentrations of $\mathrm{NH}_{4}^{+}, \mathrm{NO}_{3}^{-}$and $\mathrm{SO}_{4}^{2-}$ (they contributed $65 \%$ to the $b_{\text {ext }}$ ). On 3 February, $\mathrm{PM}_{2.5}$ decreased to $30 \mu \mathrm{g} \mathrm{m}^{-3}$, haze pollution still existed with the visibility as $6.7 \mathrm{~km}$, mainly contributed by ammonium sulfate $(67 \%)$. It can be preliminarily concluded that the intensive FW particles on CNY's Eve can influence the air quality for about 4 days by changing the main contributors of extinction coefficient from $\mathrm{EC}+\mathrm{OM}$ to ammonium sulfate. Drewnick et al. (2006) also found that after about 3 or 4 days, the aerosol mass concentrations dropped to about one-third of the concentrations for Near Year's firework-burning period, while the relative compositions of aerosols for the two periods were similar. And the mass concentrations of nitrate, sulfate and ammonium increased again after about 3 days.

Pollution gases $\left(\mathrm{SO}_{2}, \mathrm{NO}_{\mathrm{x}}\right.$, etc.) emitted during $\mathrm{FW}$ events may be oxidized to secondary organic and inorganic components that may be adsorbed onto particles (Sarkar et al., 2010). From Fig. 11a, we can find that $\mathrm{Ca}^{2+}, \mathrm{NH}_{4}^{+}, \mathrm{NO}_{3}^{-}$ and $\mathrm{SO}_{4}^{2-}$ showed peak values on $\mathrm{CNY}$ and 2 days after, suggesting the directly emission from $\mathrm{FW}$ and secondary formations through heterogeneous reactions of $\mathrm{SO}_{2}$ and $\mathrm{NO}_{\mathrm{x}}$ on crustal materials. Higher correlations were found for $\mathrm{NO}_{3}^{-}$$\mathrm{Ca}^{2+}\left(R^{2}=0.64\right)$ and $\mathrm{SO}_{4}^{2-}-\mathrm{Ca}^{2+}\left(R^{2}=0.70\right)$. The lower wind speed (1.7-2.6 $\left.\mathrm{m} \mathrm{s}^{-1}\right)$ and mixing layer heights (257$284 \mathrm{~m}$ ) helped to capture pollution gases near the ground and higher RH (74-88 \%) favored their secondary transformation and following condensation onto pre-existing aerosols at the initial 4 days after intensive $\mathrm{FW}$ emissions on CNY.

From 30 January to 4 February, the ratios of soot$\mathrm{EC} / \mathrm{NO}_{3}^{-}, \mathrm{Cl}^{-} / \mathrm{K}^{+}, \mathrm{NO}_{3}^{-} / \mathrm{SO}_{4}^{2-}$ and $\mathrm{Ca}^{2+}$ decreased first and then increased again, while to the opposite for $\mathrm{SO}_{4}^{2-} / \mathrm{K}^{+}$, suggesting the secondary formation (Fig. 11b). 

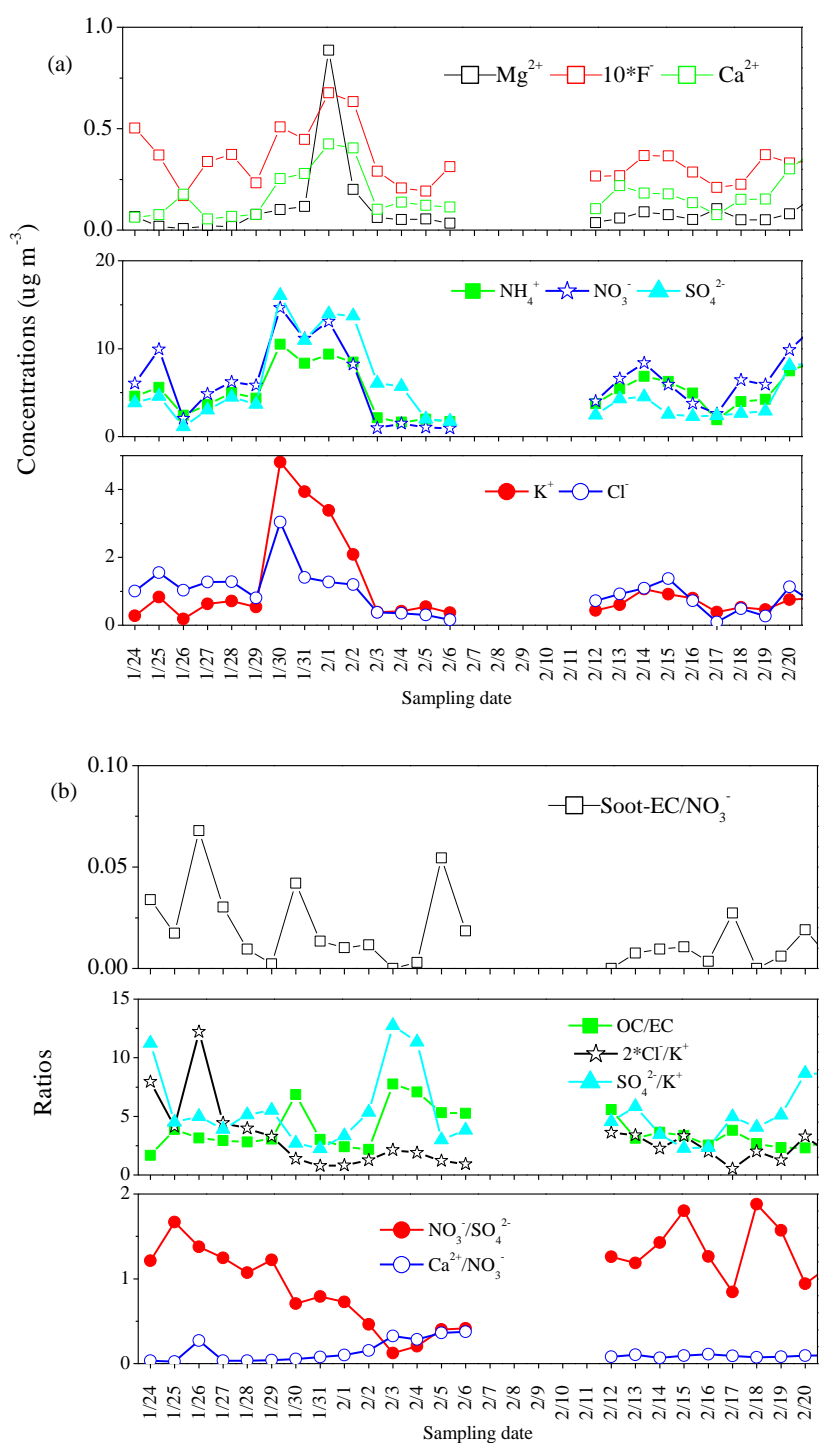

Figure 11. Time series of ions (a) and specific ratios (b) during sampling period. 30 January-7 February represents the Chinese Spring Festival in 2014; 30 January is the Chinese New Year day; 14 February is the Lantern Festival day.

Secondary formations of $\mathrm{NH}_{4}^{+}, \mathrm{NO}_{3}^{-}$and $\mathrm{SO}_{4}^{2-}$ from the gases emitted from FW were also found in other cities (Wang et al., 2007; Yang et al., 2014). During aging, the direct emission of $\mathrm{KCl}$ from fireworks (Drewnick et al., 2006) $\left(R^{2}=0.85\right.$ for $\left.\mathrm{K}^{+}-\mathrm{Cl}^{-}\right)$can react with $\mathrm{H}_{2} \mathrm{SO}_{4}$ and $\mathrm{HNO}_{3}$ to form $\mathrm{SO}_{4}^{2-}\left(R^{2}=0.76\right.$ for $\left.\mathrm{K}^{+}-\mathrm{SO}_{4}^{2-}\right)$ and $\mathrm{NO}_{3}^{-}\left(R^{2}=0.96\right.$ for $\mathrm{K}^{+}-\mathrm{NO}_{3}^{-}$), leading to the decreasing of $\mathrm{Cl}^{-} / \mathrm{K}^{+}$ratio and increasing of $\mathrm{SO}_{4}^{2-} / \mathrm{K}^{+}$ratio. Li et al. (2013) drew the same conclusion through single particle analysis as that $\mathrm{K}$ rich particles containing significant amounts of $\mathrm{S}$ in the form of $\mathrm{K}_{2} \mathrm{SO}_{4}$ at a background site under the influence of FW. It implied the existence of the aging of fresh $\mathrm{FW}$ particles via heterogeneous reactions during long-range transport. Soot
(soot-EC) can be directly introduced by firework displays (Do et al., 2012) which showed moderate correlations with $\mathrm{NO}_{3}^{-}$and $\mathrm{SO}_{4}^{2-}\left(R^{2}=0.47\right.$ and 0.56 , respectively $)$ in this study, indicating the coating of $\mathrm{NO}_{3}^{-}$and $\mathrm{SO}_{4}^{2-}$ on soot. The $\mathrm{OC} / \mathrm{EC}$ ratio peaked on CNY (as 6.8) which was mainly contributed by the increasing of $\mathrm{OC} 1, \mathrm{OC} 2$ and OPC. They are related with volatilization of the organic materials used for fireworks producing. The smelting point temperatures for polyvinyl alcohol, polyoxyethylene and shell-lac are 230 $240^{\circ} \mathrm{C}, 212^{\circ} \mathrm{C}, 115-120^{\circ} \mathrm{C}$ and the softening point for phenol formaldehyde resin is $80-85^{\circ} \mathrm{C}$, all lower than the detecting temperature for $\mathrm{OC} 2\left(230^{\circ} \mathrm{C}\right)$. Therefore, $\mathrm{OC} 1, \mathrm{OC} 2$ and $\mathrm{OPC}$ are more easily and directly emitted from FW. The initially decreasing $\mathrm{OC} / \mathrm{EC}$ ratio indicated the gradual formation of secondary (aged) organic aerosols (Feng et al., 2012). To summarize, the heterogeneous reactions of $\mathrm{SO}_{2}$ and $\mathrm{NO}_{\mathrm{x}}$ on crustal materials directly from $\mathrm{FW}$, the replacement of $\mathrm{Cl}^{-}$by $\mathrm{NO}_{3}^{-}$and $\mathrm{SO}_{4}^{2-}$, coating of $\mathrm{NO}_{3}^{-}$and $\mathrm{SO}_{4}^{2-}$ on soot and formation of secondary organic aerosols are the main aging mechanisms of FW particles.

Previous studies also indicated that metals like $\mathrm{Fe}, \mathrm{Cu}$ and $\mathrm{Mn}$ can catalyze the formation of $\mathrm{NO}_{3}^{-}$and $\mathrm{SO}_{4}^{2-}$ (Wang et al., 2007; Do et al., 2012; Feng et al., 2012). Wang et al. (2007) indicated that the heterogeneous formation of sulfate through reacting with a- $\mathrm{Fe}_{2} \mathrm{O}_{3}$ existed under moist atmosphere and was a function of $\mathrm{RH}$ and $\mathrm{HNO}_{3}$. As shown in Fig. 12 and Supplement Fig. S9, significant correlations are found between $\mathrm{NO}_{3}^{-}$and $\mathrm{Fe}, \mathrm{Cu}$ and $\mathrm{Mn}$ and between $\mathrm{SO}_{4}^{2-}$ and $\mathrm{Fe}, \mathrm{Cu}$ and $\mathrm{Mn}$ at higher $\mathrm{RH}$. It indicated the mechanism of metal-catalyzed formation of $\mathrm{NO}_{3}^{-}$and $\mathrm{SO}_{4}^{2-}$ was more likely to occur at higher RH. On the day of CNY and 2 February, the RH was 88 and $87 \%$, implying the occurrence of metal-catalyzed reactions, which may also explain the higher $\mathrm{NO}_{3}^{-}$and $\mathrm{SO}_{4}^{2-}$ concentrations on these days. The $R^{2}$ increased with the elevated RH. There are obvious increases of $R^{2}$ for $\mathrm{Fe}-\mathrm{NO}_{3}^{-}, \mathrm{Mn}-\mathrm{NO}_{3}^{-}$and $\mathrm{Cu}-\mathrm{NO}_{3}^{-}$when $\mathrm{RH}$ were $>85 \%,>85 \%$ and $>65 \%$, respectively. For the correlations of $\mathrm{Fe}-\mathrm{SO}_{4}^{2-}, \mathrm{Mn}_{-} \mathrm{SO}_{4}^{2-}$ and $\mathrm{Cu}-\mathrm{SO}_{4}^{2-}$, clear increases in $R^{2}$ were found when $\mathrm{RH}$ were $>85 \%,>85 \%$ and $>55 \%$. Then we can conclude that for Fe-catalyzed and Mncatalyzed reactions, the threshold of $\mathrm{RH}$ was around $85 \%$; for $\mathrm{Cu}$-catalyzed formation of $\mathrm{NO}_{3}^{-}$and $\mathrm{SO}_{4}^{2-}$, the thresholds of RH were around 65 and $55 \%$, respectively. For RH higher than $90 \%, R^{2}$ decreased for $\mathrm{Fe}-\mathrm{NO}_{3}^{-}, \mathrm{Cu}-\mathrm{NO}_{3}^{-}, \mathrm{Fe}-$ $\mathrm{SO}_{4}^{2-}$ and $\mathrm{Mn}_{-} \mathrm{SO}_{4}^{2-}$ which needs more data in the future to be verified and explained.

\subsubsection{Potential health risks during the aging of firework-burning particles}

After they are emitted from the intensive FW on CNY's Eve, heavy metals including $\mathrm{Vi}, \mathrm{Cr}, \mathrm{Mn}, \mathrm{Co}, \mathrm{Ni}, \mathrm{Cu}, \mathrm{Zn}, \mathrm{As}, \mathrm{Cd}$ and $\mathrm{Pb}$ decreased directly in the following 4 days (Supplement Fig. S10). It indicated that they were emitted from FW 

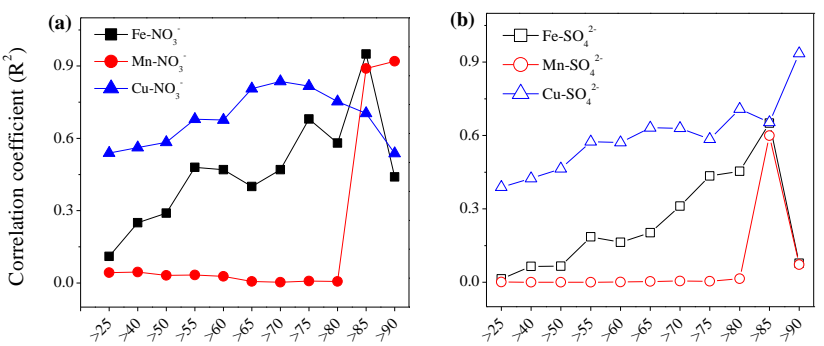

Relative humidity (\%)

Figure 12. Correlation coefficients $\left(R^{2}\right)$ of $\mathrm{NO}_{3}^{-}$and metals-Fe, $\mathrm{Mn}$ and $\mathrm{Cu}$ under certain relative humidity bins (a); correlation coefficients of $\mathrm{SO}_{4}^{2-}$ and metals-Fe, $\mathrm{Mn}$ and $\mathrm{Cu}$ under certain relative humidity bins (b). For each time of calculating the $R^{2}$, the data of $\mathrm{NO}_{3}^{-}$or $\mathrm{SO}_{4}^{2-}$ and each metal were used for corresponding relative humidity bins.

primarily and were removed mainly by dispersion and deposition during aging. Then we can assume that (1) other emission sources (coal combustion, vehicle exhaust and industrial processes were their main sources) for these metals were stable during SF period; (2) the highest concentrations of them were just the combinations of particles from the FW on 30 January and other sources on 29 January. We subtract the concentrations of elements on 29 January from the corresponding values on 30 and 31 January, 1 and 2 February for each element, respectively, to obtain the element concentrations just related with the FW particles. Considering the variations of mixing layer height (as 306, 257, 227, 284 and $248 \mathrm{~m}$ for the 5 days of 29 January-2 February) and accumulation effect, the concentrations of these elements on 30 and 31 January, 1 and 2 February were transferred by factors of $0.84,0.74,0.93$ and 0.81 , respectively. Then the $C_{95} \% \mathrm{UCL}$ values raised by $\mathrm{FW}$ particles were 7.4, 21.2, 12.0, 23.7, 0.42, $5.2,54.5,11.7,126$ and $837 \mathrm{ng} \mathrm{m}^{-3}$ of the 10 elements, respectively, for the 4 days. The non-cancer risks raised just by FW particles on CNY's Eve were below 1 ( 0.03 and 0.02 for children and adults) (Fig. 13), indicating no adverse health effects. However, the cancer risk was $1.62 \times 10^{-6}$, higher than $10^{-6}$, suggesting the FW particles were important carcinogens and should be controlled effectively, especially for the contained Cd and As. Meanwhile, the risk level for children was higher than that for adults, which meant that children were more sensitive to non-carcinogenic effects and should be kept from possible exposure to them (Yang et al., 2014). The FW should be restricted at the SF from the view of their cancer risks to human health.

\section{Conclusions}

A total of 39 elements, 10 water-soluble ions and 8 fractions of carbonaceous species were measured to fully characterize the chemical compositions in atmospheric $\mathrm{PM}_{2.5}$ in Nan-
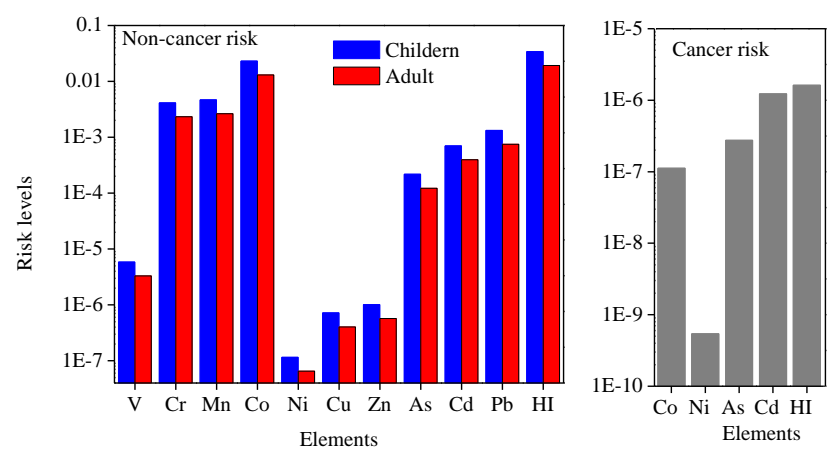

Figure 13. Non-cancer and cancer risks for heavy metals raised by intensive firework burning in Nanjing.

jing during the 2014 Chinese Spring Festival (SF). Serious regional haze pollution occurred and lasted during the whole sampling period. On Chinese New Year (CNY)'s Eve, after it peaked at 02:00, $\mathrm{PM}_{2.5}$ exponentially decreased in the following $11 \mathrm{~h}$ to the level before extensive firework-burning (FW) activities. Due to holiday effect, almost all elements decreased during SF except for $\mathrm{Al}, \mathrm{K}, \mathrm{Ba}$ and $\mathrm{Sr}$ which were related with FW. As the "spring travel rush" effect, $\mathrm{NO}_{3}^{-}$, $\mathrm{OC}$ and EC showed highest values for periods before SF, indicating the extremely high traffic flows. At the New Year's Eve celebration, about $60.1 \%$ of the $\mathrm{PM}_{2.5}$ mass was estimated to be from FW. Highly elevated $\mathrm{Ba}$ and $\mathrm{Sr}$ were also found (highly correlated with each other), indicating they can be used as the tracers of FW. The intensive FW on CNY's Eve obviously changed the chemical compositions of $\mathrm{PM}_{2.5}$, with elevated organic matter (OM) immediately, contributing $39.3 \%$ of $\mathrm{PM}_{2.5}$. The contributions of secondary ions formed by gas-particle transformations gradually increased during FW particles' aging processes. After FW particles emitted on $\mathrm{CNY}$, the contribution of $\left(\mathrm{NH}_{4}\right)_{2} \mathrm{SO}_{4}$ to extinction coefficient increased from $36 \%$ to $67 \%$; while for $\mathrm{NH}_{4} \mathrm{NO}_{3}$ and $\mathrm{EC}$, their contributions increased first and then decreased. According to tracers and principle component analysis, firework burning was the most important source of $\mathrm{PM}_{2.5}$ at this site. They contributed about half of $\mathrm{PM}_{2.5}$ during SF. Tracers for various sources (As and $\mathrm{Sb}$ for coal combustion; $\mathrm{Ba}$ and $\mathrm{Sr}$ for FW, OC and EC for vehicle emission; Ca for construction or road dust; $\mathrm{Na}^{+}$for sea salt; and $\mathrm{Li}, \mathrm{Be}$ and $\mathrm{Si}$ for soil) performed well and they varied accordantly with the contributions of corresponding sources. The FW particles emitted from CNY's Eve may undergo about aging processes of about 4 days from the variations of $\mathrm{Ba}, \mathrm{Sr}, \mathrm{NH}_{4}^{+}, \mathrm{NO}_{3}^{-}, \mathrm{SO}_{4}^{2-}$ and $\mathrm{K}^{+}$. The aging processes were characterized by heterogeneous reactions of $\mathrm{SO}_{2}$ and $\mathrm{NO}_{\mathrm{x}}$ on crustal materials directly from $\mathrm{FW}$, the replacement of $\mathrm{Cl}^{-}$by $\mathrm{NO}_{3}^{-}$and $\mathrm{SO}_{4}^{2-}$, coating of $\mathrm{NO}_{3}^{-}$and $\mathrm{SO}_{4}^{2-}$ on soot, formation of secondary organic aerosols and metal-catalyzed formation of $\mathrm{NO}_{3}^{-}$and $\mathrm{SO}_{4}^{2-}$ at higher relative humidity. For Fe-catalyzed and $\mathrm{Mn}$ catalyzed reactions, the thresholds of $\mathrm{RH}$ were around $85 \%$; 
while for $\mathrm{Cu}$-catalyzed formations of of $\mathrm{NO}_{3}^{-}$and $\mathrm{SO}_{4}^{2-}$, the thresholds of $\mathrm{RH}$ were around $65 \%$ and $55 \%$, respectively. During the aging processes, FW particles on CNY obviously changed the main contributors to the extinction coefficient from $\mathrm{EC}+\mathrm{OM}$ to ammonium sulfate. Meanwhile, higher cancer risks raised by heavy metals (especially for $\mathrm{Cd}$ and As) only related with FW particles emitted on CNY's Eve was $1.62 \times 10^{-6}$, which also imposed higher non-cancer risks to children than to adults. The results in this study will be useful for understanding the detailed compositions and aging processes of FW particles and also highlight the importance of controlling intensive firework burning in order to protect air quality and reduce the cancer risks. 
Table A1. Abbreviations glossary.

\begin{tabular}{ll}
\hline Firework burning & FW \\
Chinese New Year day & CNY \\
Spring Festival & SF \\
Lantern Festival & LF \\
Organic carbon & OC \\
Elemental carbon & EC \\
Black carbon & BC \\
Organic matter & OM \\
Relative humidity & RH \\
Inductively coupled plasma-mass spectroscopy & ICP-MS \\
Inductively coupled plasma-optical emission spectrometer & ICP-OES \\
Optically detected pyrolyzed carbon & OPC \\
Principal component analysis & PCA \\
Lifetime average daily dose & LADD \\
Inhalation rate & InhR \\
Exposure frequency & EF \\
Exposure duration & ED \\
Average body weight & BW \\
Averaging time & AT \\
Hazard quotient & HQ \\
Reference dose & RfD \\
Hazard index & HI \\
Mineral matter & MIN \\
Trace elements & TE \\
Sea salt & SS \\
Secondary inorganic aerosol & SIA \\
Unidentified matter & UM \\
Correlation coefficient & $R^{2}$ \\
Weather Research and Forecast model & WRF \\
The day before CNY & pre-CNY \\
The day before LF & pre-LF \\
The period before the Spring Festival & pre-SF \\
The period after the Spring Festival & after-SF \\
Mass calculated by adding individual components & PM \\
Gravimetrically measured particulate mass & PM \\
Visibility calculated by adding individual components & $V_{\text {cal }}$ \\
Measured visibility & $V_{\text {meas }}$ \\
Extinction coefficient & $b_{\text {ext }}$ \\
\hline &
\end{tabular}




\section{The Supplement related to this article is available online at doi:10.5194/acp-15-2167-2015-supplement.}

Acknowledgements. This work was funded by the National Natural Sciences Foundation of China (No. 41030962), scientific and technological cooperation between the governments of China and Serbia (2013(158)2-10), the grant of China Scholarship Council and the Priority Academic Program Development (PAPD) of Jiangsu Higher Education Institution.

Edited by: S. A. Nizkorodov

\section{References}

Allan, J. D., Williams, P. I., Morgan, W. T., Martin, C. L., Flynn, M. J., Lee, J., Nemitz, E., Phillips, G. J., Gallagher, M. W., and Coe, H.: Contributions from transport, solid fuel burning and cooking to primary organic aerosols in two UK cities, Atmos. Chem. Phys., 10, 647-668, doi:10.5194/acp-10-647-2010, 2010.

Attri, A. K., Kumar, U., and Jain, V. K.: Microclimate: formation of ozone by fireworks, Nature, 411, 1015, 2001.

Baptistaa, L. F. and Miguel, E. D.: Geochemistry and risk assessment of street dust in Luanda, Angola: A tropical urban environment, Atmos. Environ., 39, 4501-4512, 2005.

Cao, J. J., Wu, F., Chow, J. C., Lee, S. C., Li, Y., Chen, S. W., An, Z. S., Fung, K. K., Watson, J. G., Zhu, C. S., and Liu, S. X.: Characterization and source apportionment of atmospheric organic and elemental carbon during fall and winter of 2003 in Xi'an, China, Atmos. Chem. Phys., 5, 3127-3137, doi:10.5194/acp-5-3127-2005, 2005.

Deka, P. and Hoque, R. R.: Incremental effect of festive biomass burning on wintertime $\mathrm{PM}_{10}$ in Brahmaputra Valley of Northeast India, Atmos. Res., 143, 380-391, 2014.

Do, T. M., Wang, C. F., Hsieh, Y. K., and Hsieh, H. F.: Metals present in ambient air before and after a firework festival in Yanshui, Tainan, Taiwan, Aerosol Air Qual. Res., 12, 981-993, 2012.

Drewnick, F., Hings, S. S., Curtius, J., Eerdekens, G., and Williams, J.: Measurement of fine particulate and gas-phase species during the New Year's Fireworks 2005 in Mainz, Germany, Atmos. Environ., 40, 4316-4326, 2006.

Dutschke, A., Lohrer, C., Kurth, L., Seeger, S., Barthel, M., and Panne, U.: Aerosol Emissions from Outdoor Firework Displays. Chem. Eng. Technol., 12, 2044-2050, 2011.

Estrellan, C. R. and Iino, F.: Toxic emissions from open burning, Chemosphere, 80, 193-207, 2010.

Feng, J. L., Sun, P., Hu, X. L., Zhao, W., Wu, M. H., and Fu, J. M.: The chemical composition and sources of $\mathrm{PM}_{2.5}$ during the 2009 Chinese New Year's holiday in Shanghai, Atmos. Res., 118, 435444, 2012.

Godri, K. J., Green, D. C., Fuller, G. W., OSTO, M. D., Beddows, D. C., Kelly, F. J., Harrison, R. M., and Mudway, I. S.: Particulate oxidative burden associated with firework activity, Environ. Sci. Technol., 44, 8295-8301, 2010.
Granero, S. and Domingo, J.: Levels of metals in soils of Alcala de Henares, Spain: Human health risks, Environ. Int., 28, 159-164, 2002.

Han, Y. M., Han, Z. W., Cao, J. J., Chow, J. C., Watson, J. G., An, Z. S., Liu, S. X., and Zhang, R. J.: Distribution and origin of carbonaceous aerosol over a rural high-mountain lake area, Northern China and its transport significance, Atmos. Environ., 42, 2405-2414, 2008.

Han, Y. M., Cao, J. J., Lee, S. C., Ho, K. F., and An, Z. S.: Different characteristics of char and soot in the atmosphere and their ratio as an indicator for source identification in Xi'an, China, Atmos. Chem. Phys., 10, 595-607, doi:10.5194/acp-10-595-2010, 2010.

Huang, K., Zhuang, G. S., Lin, Y., Wang, Q., Fu, J. S., Zhang, R., Li, Deng, J. C., and Fu, Q. Y.: Impact of anthropogenic emission on air quality over a megacity-revealed from an intensive atmospheric campaign during the Chinese Spring Festival, Atmos. Chem. Phys., 12, 11631-11645, doi:10.5194/acp12-11631-2012, 2012.

Jiang, Q., Sun, Y. L., Wang, Z., and Yin, Y.: Aerosol composition and sources during the Chinese Spring Festival: fireworks, secondary aerosol, and holiday effects, Atmos. Chem. Phys. Discuss., 14, 20617-20646, doi:10.5194/acpd-14-20617-2014, 2014.

Jing, H., Li, Y. F., Zhao, J. T., Li, B., Sun, J. L., Chen, R. Gao, Y. X., and Chen, C. Y.: Wide-range particle characterization and elemental concentration in Beijing aerosol during the 2013 Spring Festival, Environ. Pollut., 192, 204-211, 2014.

Joly, A., Smargiassi, A., Kosatsky, T., Fournier, M., DabekZlotorzynska, E., Celo, V., Mathieu, D., Servranckx, R., D'amours, R., Malo, A., and Brook, J.: Characterisation of particulate exposure during fireworks displays, Atmos. Environ., 44, 4325-4329, 2010.

Kang, H. Q., Zhu, B., Su, J. F., Wang, H. L., Zhang, Q. C., and Wang, F.: Analysis of a long-lasting haze episode in Nanjing, China, Atmos. Res., 120-121, 78-87, 2013.

Kim, K. W., Kim, Y. J., and Oh, S. J.: Visibility impairment during Yellow Sand periods in the urban atmosphere of Kwangju, Korea, Atmos. Environ., 35, 5157-5167, 2001.

Kong, S. F., Han, B., Bai, Z. P., Chen, L., Shi, J. W., and Xu, Z.: Receptor modeling of $\mathrm{PM}_{2.5}, \mathrm{PM}_{10}$ and TSP in different seasons and long-range transport analysis at a coastal site of Tianjin, China, Sci. Total Environ., 408, 4681-4694, 2010.

Kong, S. F., Lu, B., Ji, Y. Q., Zhao, X. Y., Bai, Z. P., Xu, Y. H., Liu, Y., and Jiang, H.: Risk assessment of heavy metals in road and soil dust within $\mathrm{PM}_{2.5}, \mathrm{PM}_{10}$ and $\mathrm{PM}_{100}$ fractions in Dongying city, Shandong Province, China, J. Environ. Monitor., 14, 791-803, 2012.

Kong, S. F., Ji, Y. Q., Lu, B., Zhao, X. Y., Chen, L., Bai, Z. P., Xu, Y. H., Liu, Y., and Jiang, H.: Characteristic of $\mathrm{PM}_{2.5}, \mathrm{PM}_{10}$ and TSP source profiles for fugitive dust in a coastal oilfield city, China, Aerosol Air Qual. Res., accepted, doi:10.4209/aaqr.2013.06.0226, 2014a.

Kong, S. F., Wen, B., Chen, K., Yin, Y., Li, Q., Li, L., Yuan, L., and Sun, X.: Ion chemistry for atmospheric size-segregated aerosol and depositions at an offshore site of Yangtze River Delta (YRD) region, China, Atmos. Res., 147-148, 205-226, 2014 b.

Li, L., Yin, Y., Kong, S. F., Wen, B., Chen, K., Yuan, L., and Li, Q.: Altitudinal effect to the size distribution of water soluble inor- 
ganic ions in PM at Huangshan, China, Atmos. Environ., 98, 242-252, 2014.

Li, M. N. and Zhang, L.: Haze in China: current and future challenges, Environ. Pollut., 189, 85-86, 2014.

Li, P. H., Han, B., Huo, J., Lu, B., Ding, X., Chen, L., Kong, S. F., Bai, Z. P., and Wang, B.: Characterization, meteorological influences and source identification of carbonaceous aerosol during autumn-winter period in Tianjin, China, Aerosol Air Qual. Res., 2, 283-294, 2012.

Li, W. J., Shi, Z. B., Yan, C., Yang, L. X., Dong, C., and Wang, W. X.: Individual metal-bearing particles in a regional haze caused by firecracker and firework emissions, Sci. Total Environ., 443, 464-469, 2013.

Moreno, T., Querol, X., Alastuey, A., Minguillón, M. C., Pey, J., Rodriguez, S., Miró, J. V., Felis, C., and Gibbons, W.: Recreational atmospheric pollution episodes: inhalable metalliferous particles from firework displays, Atmos. Environ., 41, 913-922, 2007.

Richard, A., Gianini, M. F. D., Mohr, C., Furger, M., Bukowiecki, N., Minguillón, M. C., Lienemann, P., Flechsig, U., Appel, K., DeCarlo, P. F., Heringa, M. F., Chirico, R., Baltensperger, U., and Prévôt, A. S. H.: Source apportionment of size and time resolved trace elements and organic aerosols from an urban courtyard site in Switzerland, Atmos. Chem. Phys., 11, 8945-8963, doi:10.5194/acp-11-8945-2011, 2011.

Sarkar, S., Khillare, P. S., Jyethi, D. S., Hasan, A., and Parween, M.: Chemical speciation of respirable suspended particulate matter during a major firework festival in India, J. Hazard. Mater., 184, 321-330, 2010.

Shen, Z. X., Cao, J. J., Arimoto, R., Han, Z. W., Zhang, R. J., Han, Y. M., Liu, S. X., Okuda, T., Nakao, S., and Tanaka, S.: Ionic omposition of TSP and $\mathrm{PM}_{2.5}$ during dust storms and air pollution episodes at Xi'an, China, Atmos. Environ., 43, 29112918, 2009.

Tan, P. H., Chou, C., Liang, J. Y., Chou, C. C. K., and Shiu, C. J.: Air pollution "holiday effect" resulting from the Chinese New Year, Atmos. Environ., 43, 2114-2124, 2009.

Tao, J., Ho, K. F., Chen, L. G., Zhu, L. H., Han, J. L., and $\mathrm{Xu}, \mathrm{Z}$. C.: Effect of chemical composition of $\mathrm{PM}_{2.5}$ on visibility in Guangzhou, China, 2007 spring, Particuology, 7, 68-75, 2009.

Terzi, E., Argyropoulos, G., Bougatioti, A., Mihalopoulos, N., Nikolaou, K., and Samara, C.: Chemical composition and mass closure of ambient $\mathrm{PM}_{10}$ at urban sites, Atmos. Environ., 44, 2231-2239, 2010.

Tian, Y. Z., Wang, J., Peng, X., Shi, G. L., and Feng, Y. C.: Estimation of the direct and indirect impacts of fireworks on the physicochemical characteristics of atmospheric $\mathrm{PM}_{10}$ and $\mathrm{PM}_{2.5}$, Atmos. Chem. Phys., 14, 9469-9479, doi:10.5194/acp-14-94692014, 2014.

Tsai, H. H., Chien, L. H., Yuan, C. S., Lin, Y. C., Jen, Y. H., and Ie, I. R.: Influences of fireworks on chemical characteristics of atmospheric fine and coarse particles during Taiwan's Lantern Festival, Atmos. Environ., 62, 256-264, 2012.
Tsyro, S. G.: To what extent can aerosol water explain the discrepancy between model calculated and gravimetric $\mathrm{PM}_{10}$ and $\mathrm{PM}_{2.5}$ ?, Atmos. Chem. Phys., 5, 515-532, doi:10.5194/acp-5515-2005, 2005.

Vecchi, R., Bernardoni, V., Cricchio, D., Alessandro, A. D., Fermo, P., Lucarelli, F., Nava, S., Piazzalunga, A., and Valli, G.: The impact of fireworks on airborne particles, Atmos. Environ., 42, 1121-1132, 2008.

Wang, H. L., An, J. L., Shen, L. J., Zhu, B., Pan, C., Liu, Z. R., Liu, X. H., Duan, Q., Liu, X., and Wang, Y. S.: Mechanism for the formation and microphysical characteristics of submicron aerosol during heavy haze pollution episode in the Yangtze River Delta, China, Sci. Total Environ., 490, 501-508, 2014.

Wang, Q. Y., Cao, J. J., Shen, Z. X., Tao, J., Xiao, S., Luo, L., He, Q. Y., and Tang, X. Y.: Chemical characteristics of $\mathrm{PM}_{2.5}$ during dust storms and air pollution events in Chengdu, China, Particuology, 11, 70-77, 2013.

Wang, Y., Zhuang, G. S., Xu, C., and An, Z. S.: The air pollution caused by the burning of fireworks during the lantern festival in Beijing, Atmos. Environ., 41, 417-431, 2007.

Wehner, B., Wiedensohler, A., and Heintzenberg, J.: Submicrometer aerosol size distribution and mass concentration of the millennium fireworks 2000 in Leipzig, Germany, J. Aerosol Sci., 12, 1489-1493, 2000.

Williams, J., Drewnick, F., Hings, S.S., Curtius, J., Eerdekens, G., Klüpfel, T., and Wagner, T.: Firework emissions for Satellite Validation? Envion. Chem., 2, 94-95, 2005.

Yang, L. X., Wang, D. C., Cheng, S. H., Wang, Z., Zhou, Y., Zhou, X. H., and Wang, W. X.,: Influence of meteorological conditions and particulate matter on visual range impairment in Jinan, China, Sci. Total Environ., 383, 164-173, 2007.

Yang, L. X., Gao, X. M., Wang, X. F., Nie, W., Wang, J., Gao, R., Xu, P. J., Shou, Y. P., Zhang, Q. Z., and Wang, W. X.: Impacts of firecracker burning on aerosol chemical characteristics and human health risk levels during the Chinese New Year Celebration in Jinan, China, Sci. Total Environ., 476-477, 57-64, 2014.

Ye, C., Chen, R. S., and Young, C.: Nian: when Chinese mythology aff ects air pollution, Lancet, 383, 2125, doi:10.1016/S01406736(14)61029-1, 2014.

Yu, X. N., Shi, C. Z., Ma, J., Zhu, B., Li, M., Wang, J., Yang, S. Y., and Kang, N.: Aerosol optical properties during firework, biomass burning and dust episodes in Beijing, Atmos. Environ., 81, 475-484, 2013.

Zhang, M., Wang, X. M., Chen, J. M., Cheng, T. T., Wang, T., Yang, X., Gong, Y. G., Geng, F. H., and Chen, C. H.: Physical characterization of aerosol particles during the Chinese New Year's firework events, Atmos. Environ., 44, 5191-5198, 2010. 